\title{
Weapons Prohibitions through Immanent Critique: NGOs as Emancipatory and (De)securitizing Actors in Security Governance
}

\author{
Published in Review of International Studies 44(4): 619-653 \\ Margarita H. Petrova \\ Institut Barcelona d'Estudis Internacionals (IBEI) \\ UPF Cuitadella Campus \\ c/ Ramon Trias Fargas 25-27 \\ 08005 Barcelona, Spain \\ Email: mpetrova@ibei.org
}

\begin{abstract}
The article examines the roles of NGOs in banning cluster munitions that resulted in the 2008 Convention on Cluster Munitions and the campaign against landmines in the 1990s. It argues that NGOs have managed to move questions about the use of force from the closed decisionmaking sphere of military commanders and arms control diplomats into open public debate. Thus NGOs have simultaneously desecuritized the use of force by states, securitized certain weapons technologies, and made human beings the referent object of security. This has marked a shift from state security and strategic disarmament to human security and humanitarian disarmament, without fundamentally challenging the laws of war. However, in contrast to realist views that only militarily useless weapons ever get banned and radical critical perspectives that see new legal regimes as legitimating war and US hegemony, I argue that NGOs have engaged in immanent critique of military arguments and practices based on prevailing principles of international humanitarian law. The resulting weapon ban treaties have both restrained US policy and undermined its legitimacy. The article explore the discursive choices that underpinned the remaking of the security agenda by NGOs and their role as de/securitizing actors and emancipatory agents of change.
\end{abstract}

Keywords: weapon prohibitions, NGOs, immanent critique, emancipation, securitization and desecuritization, critical security studies 


\section{NGOs, security, and civilian protection}

Norms are usually perceived as weak or non-existent in the field of 'hard security', where state military capacities are at stake. Whenever NGOs make inroads into that terrain, as with the banning of antipersonnel landmines or cluster munitions, these achievements are often discarded as inconsequential. They make no difference in power politics either because the major military powers, such as the US, Russia, and China, have remained outside of the treaties, or presumably because the bans are on weapons of limited military utility. From both realist and some radical critical perspectives, these initiatives are insignificant at best or pernicious at worst since they contribute to legitimizing a hegemonic order of high-tech military violence.

Paradoxically, the US, the biggest military power, benefits directly from keeping its right to use weapons others renounced, and indirectly, from norms that eat away at the legitimacy of using anything but precision-guided violence. ${ }^{1}$ NGOs have just greased the wheels of hegemonic power by creating the perception of 'humanized' military conduct through banishing some means of killing civilians. However, in the process, war itself is legitimized, especially the type of war waged by the US. As pacifist and critical voices have long argued, the just war tradition and

\footnotetext{
${ }^{1}$ Marshall J. Beier, 'Dangerous Terrain: Re-Reading the Landmines Ban through the Social Worlds of the RMA', Contemporary Security Policy, 32:1 (2011), pp. 159-175; Neil Cooper, 'Humanitarian Arms Control and Processes of Securitization: Moving Weapons along the Security Continuum', Contemporary Security Policy, 32:1 (2011), p. 146; Patricia Owens, ‘Accidents Don’t Just Happen: The Liberal Politics of High-Technology “Humanitarian” War', Millennium, 32:3 (2003), pp. 595-616; Thomas W. Smith, 'The New Law of War: Legitimizing Hi-Tech and Infrastructural Violence', International Studies Quarterly, 46 (2002), pp. 355-334; David Kennedy, The Dark Sides of Virtue: Reassessing International Humanitarianism (Princeton University Press, 2004), p. 298; Thomas W. Smith, 'Can Human Rights Build a Better War?’, Journal of Human Rights, 9:1 (2010), pp. 24-44; Mandy Turner, Neil Cooper, and Michael Pugh, 'Institutionalized and Co-Opted: Why Human Security Has Lost Its Way', in David Chandler and Nik Hynek (eds), Critical Perspectives on Human Security: Rethinking Emancipation and Power in International Relations (Routledge, 2011), p. 89; Anna Stavrianakis, 'Legitimising Liberal Militarism: Politics, Law and War in the Arms Trade Treaty’, Third World Quarterly, 37:5 (2016), p. 845.
} 
international humanitarian law (IHL) do more harm than good. ${ }^{2}$ Rather than radically transforming the state- and war-based order, NGOs keep it in place by smoothing its functioning ${ }^{3}$ and legitimate its 'war-making and war-preparation practices' ${ }^{4}$ Even studies that do not adopt a critical stance point in the same direction. Norms not only constitute identities and regulate behavior. They also have 'shadow effects' - by singling out one particular type of weapons as controversial and carrying a particular stigma, be it nuclear weapons or landmines, the remaining weapons become normalized. The latter category are just acceptable 'conventional' weapons, even if they may be no less destructive than those stigmatized. ${ }^{5}$ To borrow Robert Cox's phrasing, the NGO role in security governance is 'problem-solving' - it leaves the 'prevailing social and power relationships' unquestioned and intact. ${ }^{6}$

The article challenges both the realist and, what I would call, the radical and pessimist critical positions. The latter comprises various strands of critical and poststructuralist perspectives, for the most part different from Critical Theory in security studies as formulated first by Ken Booth and Richard Wyn Jones drawing on the Frankfurt School tradition. ${ }^{7}$ First, in juxtaposition to realist

\footnotetext{
${ }^{2}$ Chris af Jochnick and Roger Normand, 'The Legitimation of Violence: A Critical History of the Laws of War', Harvard International Law Journal, 35:1 (1994), pp. 49-95; Laura Sjoberg, 'Gendered Realities of the Immunity Principle: Why Gender Analysis Needs Feminism’, International Studies Quarterly, 50 (2006), pp. 889-910. ${ }^{3}$ Miguel de Larrinaga and Claire Turenne Sjolander, '(Re)presenting Landmines from Protector to Enemy: The Discursive Framing of a New Multilateralism', in Maxwell A. Cameron, Robert J. Lawson, and Brian W. Tomlin (eds), To Walk Without Fear: The Global Movement to Ban Landmines (Oxford University Press, 1998), pp. 364391; Beier, 'Dangerous Terrain', p. 171.

${ }^{4}$ Stavrianakis, 'Legitimising Liberal Militarism', p. 841; Beier, 'Dangerous Terrain', p. 170; Cooper, 'Humanitarian Arms Control', pp. 137, 144. For a general critique of NGOs' lack of transformative effects, see, Ronnie D. Lipschutz, 'Power, Politics and Global Civil Society', Millennium, 33:3 (2005), pp.747-769.

${ }^{5}$ Nina Tannenwald, The Nuclear Taboo. The United States and the Non-Use of Nuclear Weapons since 1945. (Cambridge University Press, 2007), pp. 47, 317.

${ }^{6}$ Robert W. Cox, 'Social Forces, States and World Orders: Beyond International Relations Theory', Millennium, 50: 2 (1981), p. 128.

${ }^{7}$ Ken Booth, 'Security and Emancipation', Review of International Studies, 17:4 (1991), pp. 313-326; Ken Booth, 'Beyond Critical Security Studies', in idem. (ed.), Critical Security Studies and World Politics (Lynne Rienner, 2005), pp. 259-278; Richard Wyn Jones, 'Message in a Bottle? Theory and Praxis in Critical Security Studies', Contemporary Security Policy, 16:3 (1995), pp. 299-319; Richard Wyn Jones, Security, Strategy, and Critical Theory (Lynne Rienner, 1999).
} 
arguments about banning only useless weapons, I show that rather than being an independent causal factor determining the success of weapon prohibitions, perceptions of military utility themselves are socially constructed in the process of weapon stigmatization. What some take for granted today - that landmines and cluster munitions are obsolete weapons - is actually the result of NGO efforts to redefine political and military considerations of military necessity and usefulness. Second, despite their merits, radical critical perspectives often bracket out the ways in which the indirect legitimization of war technologies and practices that privileges the dominant power also significantly circumscribes its freedom of action. Radical critics rightly identify the NGOs' limitations, but do not offer an alternative road that can lead out of the vicious cycle of war legitimation. In this pessimist view, there is no way out, because any emancipatory moves are always already implicated in reproducing the old order and servicing the interests of Western states with the US foremost among them. ${ }^{8}$ This position is understandable given the piecemeal nature of NGO initiatives to curb war and its violence. Yet, radical critiques postulate hegemonic legitimation, but neither define it nor show how it works in practice. The fact that an arms control regime is not ambitious enough or fails to constrain state practices is taken as a sign of silencing criticism and legitimizing liberal militarism. ${ }^{9}$

This argument, that new treaties only delegitimize low-tech violence and turn the spear of liberal militarism toward the South, goes against (mostly) constructivist work ${ }^{10}$ and some optimist

\footnotetext{
${ }^{8}$ For a general critique along those lines, see, Tara McCormack, Critique, Security and Power: The Political Limits to Emancipatory Approaches (Routledge, 2010).

${ }^{9}$ Stavrianakis, 'Legitimising Liberal Militarism', p. 853. Also, 'continuity in practice suggest legitimation'; ibid, p. 847; Turner, Cooper, and Pugh, 'Institutionalized and Co-Opted', p. 90.

${ }^{10}$ Richard Price, 'Reversing the Gun Sights: Transnational Civil Society Targets Landmines', International Organization, 52:3 (1998), pp. 613-44; Kenneth R. Rutherford, 'The Evolving Arms Control Agenda: Implications of the Role of NGOs in Banning Antipersonnel Landmines', World Politics, 53 (2000), pp. 74-114; Kenneth R. Rutherford, 'A Theoretical Examination of Disarming States: NGOs and Anti-Personnel Landmines', International Politics, 37 (2000), pp. 457-478; Don Hubert, 'The Landmine Ban: A Case Study in Humanitarian Advocacy', Occasional Paper 42 (2000), Thomas J. Watson Jr. Institute for International Studies, Brown University; http://www.watsoninstitute.org/pub/op42.pdf; Charli Carpenter, 'Lost Causes': Agenda Vetting in Global Issue
} 
critical writing, ${ }^{11}$ portraying NGO roles in general, and in the field of weapons regulation specifically, as largely progressive and effective, a sign of 'new diplomacy' ${ }^{12}$ and a global 'power shift'. ${ }^{13}$ The radical critique thus echoes Foucault's insight that 'humanity installs each of its violences in a system of rules and thus proceeds from domination to domination'. Yet, Foucault still offers a glimmer of hope, for ultimately, 'the successes of history belong to those who are capable of seizing these rules... and redirect[ing] them against those who had initially imposed them' ${ }^{14}$

Drawing on constructivism in general and specific aspects from Critical Theory and desecuritization from the Copenhagen School, I present a more optimist reading of the role of NGOs in arms control through theoretical conceptualization and empirical research on immanent critique. Indeed, I find theoretical support for such an optimist reading of the transformative potential of NGOs in some poststructuralist thinking and the work of Foucault himself. Thus the

Networks and the Shaping of Human Security (Cornell University Press, 2014); Charli R. Carpenter, 'Vetting the Advocacy Agenda: Network Centrality and the Paradox of Weapon Norms', International Organization, 65: 1 (2011), pp. 69-102; Denise Garcia, Disarmament Diplomacy and Human Security: Regimes, Norms, and Moral Progress in International Relations (Routledge, 2011); Denise Garcia, 'Humanitarian Security Regimes', International Affairs, 91:1 (2015), pp. 55-75; Amanda Murdie, Help or Harm: The Human Security Effects of International NGOs (Stanford University Press, 2014); Adam Bower, 'Norms Without the Great Powers: International Law, Nested Social Structures, and the Ban on Antipersonnel Mines', International Studies Review, 17 (2015), pp. 347-373.

${ }^{11}$ Some of the critically informed, but overall positive work is done by authors themselves engaged in campaigns for humanitarian disarmament. See, Matthew Bolton and Elizabeth Minor, 'The Discursive Turn Arrives in Turtle Bay:

The International Campaign to Abolish Nuclear Weapons' Operationalization of Critical IR Theories', Global Policy, 7:3 (2016), pp. 385-395; John Borrie, 'Humanitarian Reframing of Nuclear Weapons and the Logic of a Ban', International Affairs, 90:3 (2014), pp. 625-646; Ray Acheson, 'Foregrounding Justice in Nuclear Disarmament: A Practitioner Commentary', Global Policy, 7:3 (2016), p. 405; Nick Ritchie, 'Waiting for Kant: Devaluing and Delegitimizing Nuclear Weapons', International Affairs, 90:3 (2014), pp. 601-623.

12 Andrew F. Cooper et al. (eds) Enhancing Global Governance: Towards A New Diplomacy? (United Nations University Press, 2002).

${ }_{13}^{13}$ Jessica Mathews, 'Power Shift', Foreign Affairs, 76:1 (1997), pp. 51-66.

${ }^{14}$ Michel Foucault, 'Nietzsche, Genealogy, History', in D.F. Bouchard (ed.) Language, Counter-Memory, Practice: Selected Essays and Interviews (Cornell University Press, 1977), p. 151. 
article seeks to advance a 'reconstructive', but also a bridge-building agenda in critical security studies.$^{15}$

Specifically, exploring the campaigns to ban antipersonnel landmines ${ }^{16}$ and cluster munitions, I argue that NGOs appropriate the dominant IHL discourse, orient it from military necessity to civilian protection, and turn it against powerful states - a practical example of immanent, gradual, and ongoing critique that is often dismissed precisely because it is grounded in existing structures of power. ${ }^{17}$ The hegemon loses legitimacy when it opposes new norms that the majority of states comes to accept as part of the identity of 'civilized states'. In the process, rather than shoring up consent-based hegemony, the new norms seriously undermine it - the hegemon becomes the 'rogue' outside of humanity. The only way to gain its moral credentials back, is to reorient its policies in line with norm requirements. The new norms make space for critique and become pivotal points where critique could be successfully applied. Thus by pointing out inconsistencies in IHL application from within a broadly defined IHL perspective, NGOs engage in a form of immanent critique that opens up possibilities for gradual improvement of the human condition. Similarly, while high-tech violence is indirectly legitimated compared to lowtech, more indiscriminate weapons, the standards for both are elevated in the process. When the military claim to make 'surgical' strikes or arms manufacturers to produce 'civilian friendly'

\footnotetext{
${ }^{15}$ João Nunes, 'Reclaiming the Political: Emancipation and Critique in Security Studies', Security Dialogue, 43:4 (2012), pp. 345-361; João Nunes, 'Emancipation and the Reality of Security: A Reconstructive Agenda', in Thierry Balzacq (ed.), Contesting Security: Strategies and Logics (Routledge, 2014), pp. 141-154.

${ }^{16}$ In this article, landmines and mines refers to antipersonnel landmines only.

17 'Immanent critique' (a continuous process of looking for latent potentialities in a prevailing security regime by critiquing its inconsistencies through comparison of its justifications and actual outcomes) is seen as a road to emancipation and security in the Welsh School's Critical Security Theory. See, Richard Wyn Jones, Security, Strategy, and Critical Theory (Lynne Rienner, 1999), pp. 24, 77-78, 160; Ken Booth, Theory of World Security (Cambridge University Press, 2007), p. 250.
} 
weapons leaving a 'clean battlefield', ${ }^{18}$ but fail to meet these standards, they open themselves to criticism that can lead to further constraints on how force can be legitimately used. Finally, NGOs fundamentally desecuritize the by-definition securitized realm of national defense and use of force, ${ }^{19}$ a role that has received scant attention in the existing (de)securitization literature. They politicize the use of force by bringing into public debate military decisions hitherto generally shielded from public scrutiny. As a result, they shift the referent object of security from the state and its defense interests to human beings and their suffering. This represents an inchoate emancipatory potential to work with, a place where change could start through critique. ${ }^{20}$

NGOs are certainly not a counter-hegemonic movement. The major ones are part of a global governing elite and a trend toward NGO professionalization can be seen as leading to global corporatism, ${ }^{21}$ or stunting development policy in a national context. ${ }^{22}$ Yet, NGO participation in security governance is one of the reasons why they can bring about some palpable, however piecemeal, change. As has been argued, the organizations that shape the transnational advocacy agenda and influence its chances for success are gatekeeper NGOs with resources, visibility, and central network positions. ${ }^{23}$

18 ““Civilian friendly” cluster bomb debuts against tanks', Post-Gazette National Bureau (3 April 2003); 'Making a More Humane Bomb, Textron Aims to Cut Civilian Deaths from Unexploded Munitions’, Boston Globe (12 April 2003).

${ }^{19}$ Barry Buzan, Ole Wæver and Jaap de Wilde, Security: A New Framework for Analysis (Colorado: Lynne Rienner, 1998), pp. 27-28.

${ }^{20}$ Ken Booth, 'Security and Emancipation', Review of International Studies, 17:4 (1991), pp. 313-326; Booth, 'Beyond Critical Security Studies', pp. 265-7; Wyn Jones, Security, pp. 160, 312; João Nunes, 'Reclaiming the Political'. For the emancipatory role of NGOs and human rights law in curbing American violations in the 'war on terror', see, Ruth Blakeley, 'Human Rights, State Wrongs, and Social Change: the Theory and Practice of Emancipation’, Review of International Studies, 39:3 (2013), pp. 599-619.

${ }^{21}$ Marina Ottaway, 'Corporatism Goes Global: International Organizations, Nongovernmental Organization Networks, and Transnational Business’, Global Governance, 7:3 (2001), pp. 265-293.

22 Terje Tvedt, 'International Development Aid and Its Impact on a Donor Country: A Case Study of Norway', European Journal of Development Research, 19:4 (2007), pp. 614-635.

${ }^{23}$ Clifford Bob, The Marketing of Rebellion. Insurgents, Media, and International Activism (Cambridge University Press, 2005); Clifford Bob (ed.), The Internaitonal Struggle for New Human Rights (University of Pennsylvania Press, 2009); Carpenter, 'Vetting the Advocacy Agenda'; Carpenter, 'Lost Causes'. 
At the discursive level, NGOs have started their critique with the core IHL principle balancing humanitarian costs and military interests that all too often privileges the military side of the equation. In the process, they have gradually tried to extricate themselves from the IHL framework, but so far have not managed to pose a radical challenge to military practices, let alone to the acceptability of war. However, in those cases where they have focused their attention, NGOs have tipped the scales toward the humanitarian side by elevating the importance of civilian protection and diminishing the military and political value of specific weapons. That does not mean that civilian suffering on the whole has lessened or that wars are less likely to occur, only that NGO campaigning has curbed particular uses of force and the suffering they inflict upon civilians. In a world of 'moral limit and possibility', ${ }^{24}$ this contribution should not be easily discarded.

In what follows, first, I engage with the different critical views about the emancipatory potential of NGOs in security and arms control and outline the theoretical arguments about NGO use of immanent critique as a tool for norm transformation and the processes of (de)securitization that this involves. Second, a genealogy of the emergence of the idea of weapon obsolescence is presented that traces the discursive practices through which NGOs redefined the balance between humanitarian costs and military gains in the case of cluster munitions and landmines. Then, I examine the impact of stigmatizing cluster munitions on US policies and practices and argue that the US has been constrained in important ways despite its opposition to banning those weapons. The conclusion reflects on the contributions and limitations of NGOs as agents of change in security governance.

\footnotetext{
${ }^{24}$ Richard Price, 'Moral Limit and Possibility in World Politics’, International Organization, 62:2 (2008), pp. 191220.
} 
Immanent critique and NGOs as emancipatory agents: difference and shared visions in critical approaches

According to Wyn Jones, '[r]ather than criticize the prevailing order in terms of some blueprint for an ideal society, critical theory criticizes it on the basis of the unfulfilled potential that already exists within it - that is, through a form of immanent critique'. ${ }^{25}$ Immanent critique implies 'comparing the justifications of [prevailing security] regimes with actual outcomes' with the goal of showing how 'the prevailing structures and regimes are found to fail grievously on their own terms' ${ }^{26}$ This is possible because all rulers make some universal claims to shore up their legitimacy. ${ }^{27}$ By highlighting 'the contradiction... between concrete social formations and their ideologies', ${ }^{28}$ immanent critique seeks 'to transform legitimations into emancipatory weapons... and mak[e] the ideal real' ${ }^{29}$ This opens the door to transforming the old order in ways that free human potential and could ultimately lead to human emancipation.

The concepts of immanent critique and emancipation date back to the work of Marx, ${ }^{30}$ and especially Max Horkheimer and Theodor Adorno and have undergone significant evolution in the thinking of Horkheimer himself and later scholars from the Frankfurt School. In Horkheimer’s early work, emancipation meant freeing humankind from the domination of nature by making proper use of the forces of production. Later the focus turned to emancipation from human

\footnotetext{
${ }^{25}$ Richard Wyn Jones, 'On Emancipation: Necessity, Capacity and Concrete Utopias', in Ken Booth (ed.) Critical Security Studies and World Politics (Lynne Rienner, 2005), p. 220, emphasis in original.

${ }^{26}$ Wyn Jones, 'Message in a Bottle', p. 312, emphasis in original; Blakeley, 'Human Rights, State Wrongs', pp. 600-601.

${ }^{27}$ Horkheimer cited in Robert J. Antonio, 'Immanent Critique as the Core of Critical Theory: Its Origins and Developments in Hegel, Marx and Contemporary Thought', British Journal of Sociology, 32: 3 (1981), p. 338.

${ }^{28}$ Antonio, 'Immanent Critique as the Core of Critical Theory', p. 334.

${ }^{29}$ Antonio, 'Immanent Critique as the Core of Critical Theory', p. 338.

${ }^{30}$ Antonio, 'Immanent Critique as the Core of Critical Theory'.
} 
exploitation with the proletariat postulated as the agent of such emancipatory change. ${ }^{31}$ Following WWII, Horkheimer and Adorno came to a rather pessimist conclusion that the rise of instrumental rationality, necessary for the subjugation of nature, had also led to human oppression reaching an apogee in the Nazi concentration camps. Thus there was no longer an immanent emancipatory potential, leading Adorno to conclude that 'nothing complicitous with this world can have any truth' ${ }^{32}$ Immanent critique transformed into a form of 'unrelenting negativity' and 'dissent' as any attempt to 'suggest alternatives... would immediately be reified and form yet another layer in the already over-determined structures of domination'. ${ }^{33}$ The intellectuals who were supposed to be the vehicles of emancipation assumed the role of permanent critics, detached from society and as a result the link between theory and praxis and between immanent critique and emancipation was severed. Indeed, in his late work Adorno questioned the very possibility of immanent critique as no standards of critique inherent in an oppressive and totalizing society could be found. ${ }^{34}$

Here one finds parallels to the poststructuralist criticism of Critical Theory (CT) for holding up emancipation as a grand 'meta-narrative' that is universally valid. ${ }^{35}$ From a poststructuralist perspective, any attempts toward emancipation are just a cover for domination. Instead, difference is to be celebrated. There are no grounds for immanent critique as any critique that is internal to one discourse is external to another. ${ }^{36}$ Poststructuralist approaches insist that no interpretation is better than another and casting off one domination just leads to another. ${ }^{37}$ Still, they share common

\footnotetext{
${ }^{31}$ Antonio, 'Immanent Critique as the Core of Critical Theory', p. 334.

${ }^{32}$ Quoted in Wyn Jones, 'On Emancipation', p. 222.

${ }^{33}$ Wyn Jones, 'Message in a Bottle', pp. 306-307.

${ }^{34}$ See, James Gordon Finlayson, 'Hegel, Adorno and the Origins of Immanent Criticism', British Journal for the History of Philosophy, 22:6 (2014), pp. 1157-1158.

${ }^{35}$ Columba Peoples and Nick Vaughan-Williams, Critical Security Studies: An Introduction (Routledge, 2010), pp. 29-30.

${ }^{36}$ Craig Browne, 'The End of Immanent Critique?’, European Journal of Social Theory, 11:1 (2008), pp. 10-11.

${ }^{37}$ Foucault, 'Nietzsche, Genealogy, History', p. 151.
} 
ground with CT by engaging in a form of continuous critique that adherents to both poststructuralist and CT approaches see as emancipatory. ${ }^{38}$

Wyn Jones emphasizes that emancipation is not an endpoint, but a process of striving for ‘concrete, realizable utopias', an 'always unfinished business' that requires constantly moving to the next stage of immanent critique. ${ }^{39}$ In Foucault's late work, one can detect similarities with this emancipatory focus of CT. According to Foucault, '[c]riticism... consists of analyzing and reflecting upon limits... and the point... is to transform the critique conducted in the form of necessary limitation into a practical critique that takes the form of a possible crossing-over' ${ }^{40}$ Critique 'is seeking to give new impetus, as far and wide as possible, to the undefined work of freedom'. Similar to CT's emphasis on praxis and immanent potentialities for transformation, Foucault argues that critical work has to 'put itself to the test... of contemporary reality, both to grasp the points where change is possible and desirable, and to determine the precise form this change should take'. ${ }^{41}$ Indeed, he goes on to say that rather than 'global or radical' projects, he prefers ‘the very specific transformations that have proved to be possible in the last twenty years', citing progress in authority and gender relations. ${ }^{42}$ The poststructuralist criticism of CT that by being 'partial and local', it just reifies structures of dominance is also on Foucault's mind. And he answers it similarly to Wyn Jones's take on emancipation as an 'always unfinished business ${ }^{43}$ _

\footnotetext{
${ }^{38}$ David Campbell, 'Poststructuralism', in Tim Dunne, Milja Kurki and Steve Smith (eds), International Relations Theories: Discipline and Diversity (Oxford University Press, 2010), pp. 222-223, 235; Wyn Jones, 'On Emancipation', p. 217-219; K.M. Fierke, Critical Approaches to International Security (Polity, 2007), p. 189; Christopher S. Browning and Matt McDonald, 'The Future of Critical Security Studies: Ethics and the politics of security', European Journal of International Relations, 19:2 (2011), pp. 239, 244; Turner, Cooper, and Pugh, 'Institutionalized and Co-Opted', p. 93.

${ }^{39}$ Wyn Jones, 'On Emancipation', p. 230. Also, Booth, Theory of World Security, p. 113; Nunes, 'Reclaiming the Political', p. 353.

${ }^{40}$ Michel Foucault, 'What Is Enlightenment?', in Paul Rabinow (ed.), Ethics: Subjectivity and Truth. The Essential Works of Michel Foucault, 1954-1984, Vol. 1 (The New Press, 1997), p. 315.

${ }^{41}$ Foucault, 'What Is Enlightenment?', p. 316.

${ }^{42}$ Foucault, 'What Is Enlightenment?', p. 316.

${ }^{43}$ Wyn Jones, 'On Emancipation’, p. 230.
} 
because 'the possibility of moving beyond [our limits], is always limited and determined,... we are always in the position of beginning again'. ${ }^{44}$

Given Foucault's focus on discourse as an all-encompassing system of meaning and 'practices that systematically form the objects of which they speak' ${ }^{45}$ his work, and respectively poststructuralist approaches, have been criticized for leaving little scope for agency and emancipatory change. ${ }^{46}$ Change in Foucault can happen above all through discourse and its strategic use. This includes 'the shifts and reutilization of identical formulas for contrary objectives' ${ }^{47}$ one can seize the rules and 'redirect them against those who had initially imposed them' ${ }^{48}$ Thus, ‘[d]iscourse transmits and produces power; it reinforces it, but also undermines and exposes it, renders it fragile and makes it possible to thwart it' ${ }^{49}$ Despite predominantly linking agency to discourse, in Foucault we can still discern a notion of intentional agency residing in each and every one working 'upon ourselves as free beings', ${ }^{50}$ and particularly, among the '“specific intellectuals" who use their expert knowledge to challenge the prevailing "regime of truth", ${ }^{51}$ with Robert Oppenheimer's efforts to highlight the threat of nuclear weapons given as an example. ${ }^{52}$

\footnotetext{
${ }^{44}$ Foucault, 'What Is Enlightenment?', pp. 316-317.

${ }^{45}$ Michel Foucault, Archeology of Knowledge (Routledge, 2002), p. 54.

${ }^{46}$ Richard Rorty, 'Beyond Nietzsche and Marx', London Review of Books, 3:3 (19 February 1981), pp. 5-6; Edward W. Said, 'Foucault and the Imagination of Power', in David Couzens Hoy (ed.), Foucault: A Critical Reader (Basil Blackwell Ltd, 1986), p. 151; Anthony Giddens, 'Critique of Foucault', in Philip Cassell (ed.), The Giddens Reader (Palgrave Macmillan, 1993), p. 232.

${ }^{47}$ Michel Foucault, The History of Sexuality. Volume 1 (Pantheon Books, 1978), p. 100.

${ }^{48}$ Michel Foucault, 'Nietzsche, Genealogy, History', in D.F. Bouchard (ed.) Language, Counter-Memory, Practice: Selected Essays and Interviews (Cornell University Press, 1977), p. 151.

${ }^{49}$ Foucault, The History of Sexuality. Volume 1, p. 101. This is how discourse was used in the movement toward accepting homosexuality as natural.

${ }^{50}$ Foucault, 'What Is Enlightenment?', p. 316. Similarly, Foucault sees resistance to power at the micro, individual level, 'resisting injustices at the particular point where they manifest themselves'; David Couzens Hoy, 'Power, Repression, Progress: Foucault, Lukes, and the Frankfurt School’, in idem (ed.), Foucault: A Critical Reader, p. 143.

${ }^{51}$ Wyn Jones, 'Message in a Bottle', p. 312.

${ }^{52}$ Michel Foucault, 'Truth and Power', in James D. Faubion (ed.), Power. The Essential Works of Michel Foucault, 1954-1984, Vol. 3 (The New Press, 1997), pp. 127-128.
} 
This connection between discourse, praxis, and agency is better developed in Antonio Gramsci's notion of 'organic intellectuals' who, according to Wyn Jones, can join forces with social movements working on 'issues, pertinent to the struggle for emancipation' ${ }^{53}$ and embracing the perspective of " "the poor, the disadvantaged, the voiceless, the unrepresented, the powerless”... for whom the present world order is a cause of insecurity' ${ }^{54}$ In contrast to the earlier Marxist focus on class struggle and the proletariat as a driving force, Gramsci envisioned a 'war of position', led by intellectuals and permeating the whole of society - 'a slow, incremental, even molecular, struggle to break down the prevailing hegemony and construct an alternative counterhegemony to take its place'. ${ }^{55}$ Whereas in Adorno the role of intellectuals was at best to send a 'message in a bottle' without a concrete addressee, Gramsci placed the emphasis on actorness. ${ }^{56}$ This is something Booth and Wyn Jones pick up in their writing. Critical security scholars are seen as the 'organic intellectuals', while 'new social movements' and 'global civil society' are envisioned as the active emancipatory forces. ${ }^{57}$ However, little has been said about 'practical transformative politics ${ }^{58}$ and the actual ways in which social movements and NGOs perform those functions. In this article, I seek to illustrate how NGOs can serve as emancipatory agents, including by undertaking immanent critique to undermine military arguments about appropriate use of force. I trace both the discursive practices of NGOs and their results to show, that despite realist and radical critiques, NGOs are neither irrelevant nor always contributing to the legitimation of existing power structures.

\footnotetext{
${ }^{53}$ Wyn Jones, 'Message in a Bottle’, p. 309.

${ }^{54}$ Wyn Jones, 'Message in a Bottle', p. 311, 309, quoting also Edward Said, Representations of the Intellectual (London: Vintage, 1994), p. 84.

${ }^{55}$ Wyn Jones, 'Message in a Bottle', p. 312.

${ }^{56}$ Wyn Jones, 'Message in a Bottle'.

${ }^{57}$ Wyn Jones, 'Message in a Bottle', p. 304; Booth, 'Security and Emancipation', p. 326; Dunne and Wheeler, “'We the Peoples”, p. 18; Craig N. Murphy, 'The Promise of Critical IR, Partially Kept', Review of International Studies, 33:S1 (2007), pp. 117-133.

${ }^{58}$ Nunes, 'Reclaiming the Political', p. 346.
} 
The article builds upon insights from CT and securitization theory to analyze NGOs’ roles in security governance and demonstrate the need to make political choices even if they are never perfect nor immune from critique. It thus charts a role for NGOs in the middle ground between the realist dismissal of NGOs' and their rejection by radical critics. While acknowledging the limitations of NGO contributions, the article engages in an evaluation of their contributions grounded in political realities. Radical critiques of NGOs in security share Adorno's pessimist outlook and detached stance avoiding any complicity with existing power. The 'negative or deconstructive critique ${ }^{59}$ has proliferated in security studies, but 'providing a normative agenda and informing political change' has considerably lagged behind. ${ }^{60}$ Critique itself is certainly political practice and overcoming oppression remains its guiding light. Yet critique alone provides little practical guidance about the way to dismantle oppressive power structures or achieve true peace. The radical critical stance is often easier to adopt than the more reformist, but actively political one envisioned by CT. ${ }^{61}$ By trying to promote change in this world, one inevitably needs to make choices and compromises. The point is to be aware of the costs different choices carry and assume responsibility for the choices made. This applies to both critical scholars engaged in

\footnotetext{
${ }^{59}$ Keith Krause and Michael C. Williams, 'Preface: Toward Critical Security Studies', in Keith Krause and Michael C. Williams, (eds) Critical Security Studies: Concepts and Cases (UCL Press, 1997), p. xiii.

${ }^{60}$ Nunes, 'Reclaiming the Political', p. 348. Work in the normative and reconstructive direction has since made headways. See, Matt McDonald Security, the Environment and Emancipation: Contestation over Environmental Change (Routledge, 2012); Anthony Burke, 'Security Cosmopolitanism', Critical Studies on Security, 1:1 (2013), pp. 13-28; Blakeley, 'Human Rights, State Wrongs'; João Nunes, Security, Emancipation and the Politics of Health: A New Theoretical Perspective (Routledge, 2014); Nunes, 'Emancipation and the Reality of Security'; Anthony Burke, Katrina Lee-Koo, and Matt McDonald (eds) Ethics and Global Security: A Cosmopolitan Approach (Routledge, 2014); Anthony Burke (2015) 'Security cosmopolitanism: the next phase', Critical Studies on Security, 3:2 (2015), pp. 190-212; Jonna Nyman and Anthony Burke (eds) Ethical Security Studies: A New Research Agenda (Routledge, 2016).

${ }^{61}$ Similarly, Wæver argues that the radical poststructuralists' position on the concept of security is 'safe' and 'unproblematic', whereas securitization scholars 'need to make ultimately... political choices'; Ole Wæver, 'Securitizing Sectors? Reply to Eriksson', Cooperation and Conflict, 34:3 (1999), p. 339. Also, Lene Hansen, 'Reconstructing Desecuritization: The Normative-Political in the Copenhagen School and Directions for How to Apply It', Review of International Studies, 38:3 (2012), p. 534-536.
} 
advocacy and the NGOs themselves. ${ }^{62}$ In the end, even radical critics such as David Kennedy, according to whom 'law may do more to constitute and legitimate than restrain violence', ${ }^{63}$ lay their hopes for humanitarianism in practical, political action and assumption of moral responsibility for decisions to 'kill or let live' ${ }^{64}$ Like purist humanitarians, radical critics use 'the voice of principle [that] also detaches itself from responsibility' to stage themselves 'outside of power' ${ }^{65}$ Yet, 'the best international humanitarianism blends... voices, speaking to power and as power'. It is the tension between ethical commitments and 'cost-benefit calculations, and shrewd participation in statecraft' that 'drives [humanitarianism] to renewal' ${ }^{66}$ Critical reasoning remains important,${ }^{67}$ but ultimately humanitarian actors need to accept that humanitarianism is always political, to embrace action, and shoulder responsibility for its consequences. ${ }^{68}$

I argue that NGOs have sought to do exactly this - to reconnect abstract IHL principles to ethical and political questions about the limits that should be imposed on violence. Aware of the all-encompassing and constraining nature of IHL, they have used its core principles of distinction and proportionality to open up spaces for change by turning IHL language against its consummate military users. While IHL legitimizes certain types of warfare, it has also provided the tools to challenge military practices.

What NGOs manage to achieve will always fall short of their objectives and an ideal of radical transformation of power relations and abolishing violence in war. Yet, to the extent that progress is made and a critical attitude continues to inform NGO work, arguably emancipation is,

\footnotetext{
${ }^{62}$ Here, I will not focus on the practices of critical scholars and the dilemmas their involvement in NGO work raise. On this, see, for example, Bolton and Minor, 'The Discursive Turn Arrives in Turtle Bay'.

${ }^{63}$ David Kennedy, 'Lawfare and Warfare', in James Crawford and Martti Koskenniemi (eds), The Cambridge Companion to International Law (Cambridge University Press, 2012), p. 181.

${ }^{64}$ Kennedy, 'Lawfare and Warfare', p. 181-182.

${ }^{65}$ Kennedy, Dark Sides of Virtue, p. 346.

${ }^{66}$ Kennedy, Dark Sides of Virtue, p. 343.

${ }^{67}$ Kennedy, Dark Sides of Virtue, p. 353.

${ }^{68}$ Kennedy, Dark Sides of Virtue, p. 354-355.
} 
however slowly, underway. Ultimately the question is, do NGOs ameliorate or make things worse? Is a world with bans on landmines and cluster munitions, or with an arms trade regime, with all their intended and unintended consequences, better or worse than a world without them? Apart from the direct effects on state practice and human insecurity on the ground, does piecemeal change in IHL somehow preclude or facilitate bigger strides in the long term? Or does it have no bearing either way? And then what are the alternative, truly and radically transformative pathways? I argue that modest change through immanent critique opens up new horizons and helps imagining alternative worlds where violence is less acceptable. The article thus aims at contributing to the 'reconstructive' in contrast to the 'deconstructive' agenda in critical security studies, ${ }^{69}$ while at the same time bridging different strands of critical thinking - immanent critique and emancipation from CT and desecuritization from securitization theory.

\section{NGOs as (de)securitizing actors}

Whereas Booth and Wyn Jones emphasize immanent critique as a tool and new social movements as the agents on the road to emancipatory transformation of security, Jürgen Habermas, another scholar within the Frankfurt school, on whose work critical IR scholars draw, ${ }^{70}$ helps establish a link to securitization theory. The Welsh (or Aberystwyth) school of Critical Theory stands apart from the Copenhagen school and securitization theory. However, some of the distinctions between the two can be overdrawn. CT focuses on individual security, while securitization theory on 'the

\footnotetext{
${ }^{69}$ Nunes, 'Reclaiming the Political’; Nunes, 'Emancipation and the Reality of Security'.

${ }^{70}$ See Andrew Linklater, The Transformation of Political Community: Ethical Foundations of the Post-Westphalian Era (Polity 1998); Andrew Linklater, Critical International Relations Theory: Citizenship, State and Humanity (Routledge, 2007).
} 
middle scale of limited collectivities' between the individual and humankind. ${ }^{71}$ Nevertheless, critical theorists have emphasized the security of 'people (as individuals and groups)' ${ }^{72}$ 'men and women and communities', ${ }^{73}$ and the 'ultimate collectivity of individuals, common humanity', ${ }^{74}$ rather than atomized individuals. The second distinction, that while CT focuses on emancipation, securitization theory makes no normative claims, ${ }^{75}$ on closer inspection does not fully hold up either. After all, the Copenhagen school indicates an explicit preference for desecuritization as 'the optimal long-range option'. ${ }^{76}$ And as has been noted, desecuritization - bringing issues back into politics and open discussion - comes close to the Habermasian notion of communicative action as the road to normative agreement and democratic politics. ${ }^{77}$

Despite this preference for desecuritization, the desecuritization process has been largely underdeveloped in securitization theory. ${ }^{78}$ This has changed with Hansen's comprehensive overview of the various theoretical premises and empirical applications of desecuritization, among other works focused on desecuritization. ${ }^{79}$ Hansen identified four major forms of desecuritization:

\footnotetext{
${ }^{71}$ Buzan, Wæver, and de Wilde, Security, p. 36.

${ }^{72}$ Booth, 'Security and Emancipation', p. 319.

${ }^{73}$ Wyn Jones, Security, Strategy, and Critical Theory, p. 159.

${ }^{74}$ Booth, 'Beyond Critical Security Studies', p. 267; Tim Dunne and Nicholas J. Wheeler, “"We the peoples”: Contending Discourses of Security in Human Rights Theory and Practice’, International Relations, 18:1 (2004), p. 10.

${ }^{75}$ Buzan, Wæver and de Wilde, Security: A New Framework, pp. 34-35; Wæver, 'Securitizing Sectors', p. 335.

${ }^{76}$ Buzan, Wæver and de Wilde, Security: A New Framework, p. 29; Wæver, 'Securitizing Sectors', p. 335.

${ }^{77}$ Wyn Jones, 'On Emancipation', p. 218; Rita Taureck 'Securitization Theory and Securitization Studies', Journal of International Relations and Development, 9:1 (2006), p. 59; Browning and McDonald, 'Future of Critical Security Studies', p. 245; Hansen, 'Reconstructing Desecuritization’, p. 527, 529; Matt McDonald, 'Contesting Border Security: Emancipation and Asylum in the Australian Context', in Thierry Balzacq (ed.), Contesting Security: Strategies and Logics (Routledge, 2014), pp. 154-168.

${ }^{78}$ Aradau, 'Security and the Democratic Scene', p. 389.

${ }^{79}$ Hansen, 'Reconstructing Desecuritization'; Bahar Rumelili, 'Identity and Desecuritisation: the Pitfalls of Conflating Ontological and Physical Security', Journal of International Relations and Development, 18 (2015), pp. 52-74; Mark B. Salter, 'Securitization and Desecuritization: a Dramaturgical Analysis of the Canadian Air Transport Security Authority', Journal of International Relations and Development, 11 (2008), pp. 321-349; Paul Roe, 'Securitization and Minority Rights: Conditions of Desecuritization', Security Dialogue, 35:3 (2004), pp. 279-294; Thierry Balzacq, Sara Depauw and Sarah Léonard, 'The Political Limits of Desecuritization: Security, Arms Trade, and the EU's Economic Target', in Thierry Balzacq (ed.), Contesting Security: Strategies and Logics (Routledge, 2014), pp. 104-121; Philippe Bourbeau and Juha A. Vuori, 'Security, Resilience and Desecuritization: Multidirectional Moves and Dynamics', Critical Studies on Security, 3:3 (2015), pp. 253-268; Jonathan Luke Austin
} 
1/ 'stabilisation' (an issue is framed in non-security terms within an otherwise conflictual context that stabilization placates); 2/ 'replacement' (an issue is desecuritized, while another issue is securitized in its place); 3/ 'rearticulation' (the dangerous situation is resolved); 4/ 'silencing' (desecuritization equates depoliticization, which might obscure existing insecurities) ${ }^{80}$ According to Hansen, these four ideal-types provide an exhaustive framework for analyzing current instances of desecuritization, although the lines among them may be blurred and 'further theorization of the relationship between the three spheres of the securitised, the politicized and the non-politicised' is needed. $^{81}$

Given that the ideal types are derived from different theoretical understandings of politics, one can detect a certain division between CT and poststructuralist approaches. CT allows for desecuritization through stabilization and rearticulation, while poststructuralism focuses on replacement. Both emphasize the dangers of silencing when desecuritization has the effect of shrouding causes of insecurity from the public sight. ${ }^{82}$ In the first type, desecuritization aims at and results in stabilizing conflictual relations through a slow process of transforming security dynamics. In the second 'replacement' type, the function of one securitization is simply fulfilled by another securitization. It is not clear, however, if the substituting securitization is somehow necessitated by the first. In broad terms, all securitizations can be seen as ultimately having the same function of identity stabilization. ${ }^{83}$ It remains unclear if one securitization can be dispelled only if another one is proffered as a better fit with a situation or actor interests.

and Philippe Beaulieu-Brossard, '(De)securitisation Dilemmas: Theorising the Simultaneous Enaction of Securitisation and Desecuritisation’, Review of International Studies, 44:2 (2018), 301-323.

${ }^{80}$ Hansen, 'Reconstructing Desecuritization', p. 529.

${ }^{81}$ Hansen, ‘Reconstructing Desecuritization’, pp. 539, 545-546.

${ }^{82}$ Lene Hansen, 'The Little Mermaid's Silent Security Dilemma and the Absence of Gender in the Copenhagen School', Millennium, 29:2 (2000), pp. 289-306.

${ }^{83}$ David Campbell, Writing Security: United States Foreign Policy and the Politics of Identity (University of Minnesota Press, 1992); Andreas Behnke, 'No Way Out: Desecuritization, Emancipation and the Eternal Return of the Political - A Reply to Aradau’, Journal of International Relations and Development, 9 (2006), pp. 62-69; 
Despite their different theoretical underpinnings, in practice desecuritization dynamics often blur the boundaries among the ideal-types. Whatever the intended or unintended effects of desecuritization, on which the ideal-types rest, little is said about their dynamics. I argue that drawing on Habermas's communicative action and CT's immanent critique is a fruitful way to conceptualize the discursive dynamics of desecuritization. The core of securitization processes is the reification of the inside-outside exclusionary logic. ${ }^{84}$ Communicative action underlines the move of issues into the public domain and the process through which the boundaries between 'us' and a threatening 'them' are renegotiated. ${ }^{85}$ Yet, the ways in which communicative action is to take place are not well defined in securitization theory. ${ }^{86}$ Immanent critique can be one such way to illustrate how actors can unravel the 'logic of security'. ${ }^{87}$

I emphasize four elements in desecuritization that hold parallels with Habermas's communicative action before showing how immanent critique can lead to desecuritization in practice. Although elements of desecuritization aligning with notions of the public space are highlighted, I do not argue that desecuritization is all about the 'better argument' and persuasion. Indeed, immanent critique is often employed in a strategic manner, seeking to structure the premises of the discursive contest to one's own advantage. First, desecuritization implies per definition a move back to the domain of normal and open politics, where debate takes place and different points of view and interests are taken into account. In this take, desecuritization is a process of politicization rather than silencing. Second, a larger number of actors who have a stake

\footnotetext{
Hansen, 'Reconstructing Desecuritization', p. 541. However, Rumelili, ‘Identity and Desecuritisation’ distinguishes between securitizations involving ontological and physical security and thus highlights the potential destabilizing effects of desecuritizations that threaten the ontological security of identity.

${ }^{84}$ Roxanne Lynn Doty 'Immigration and the Politics of Security', Security Studies, 8:2 (1998), pp. 71 — 93.

${ }^{85}$ Hansen, 'Reconstructing Desecuritization', pp. 531-533.

${ }^{86}$ Browning and McDonald, 'Future of Critical Security Studies’, p. 246.

${ }^{87}$ For example, Fierke uses immanent critique to show the inconsistencies in the logic and practices of the 'war on terror'; Fierke, Critical Approaches, pp. 170-184.
} 
in an issue are involved, and thus desecuritization entails democratization of the political process. Third, the referent object to be protected is redefined or changed, a process that usually involves transcending narrow, exclusionary groups. From the CT perspective, the referent object would be the most insecure and vulnerable groups ${ }^{88}$ or global humanity itself. ${ }^{89}$ Fourth, non-military measures are used while issue urgency and politicization are high.

I start with securitization theory's main proposition that there are no intrinsic 'security issues'. Instead issues are securitized through an intersubjective process that involves a speech act, through which authoritative, securitizing actors portray something as an existential threat to a particular referent object, and a relevant audience accepts the legitimacy of that claim, which opens the door for 'emergency measures... outside the bounds of political procedure'.${ }^{90}$ As a result, the issue is lifted 'above politics' and needs to be addressed urgently. If not, survival of the referent object is under question.

The above reflects the basic constructivist idea that security issues are discursively and intersubjectively constituted and that 'material resources only acquire meaning for human action through the structure of shared knowledge in which they are embedded ${ }^{91}$ Relevant for this study, perceptions of technical features of weapons systems and their military utility are not objective facts insusceptible to interpretation. ${ }^{92}$ Whereas securitization theory focuses predominantly on authoritative state actors, such as government officials or military figures, the article examines the role of NGOs in (de)securitizing processes as 'signifying agents actively engaged in the

\footnotetext{
${ }^{88}$ Wyn Jones, 'Message in a Bottle'; Wyn Jones, Security; Nunes, Security, Emancipation, pp. 33-34.

${ }^{89}$ Booth, 'Beyond Critical Security Studies'.

${ }^{90}$ Buzan, Wæver, and de Wilde, Security, p. 24.

${ }^{91}$ Alexander Wendt, 'Constructing International Politics', International Security, 20:1 (1995), p. 73; Emanuel Adler, 'Seizing the Middle Ground: Constructivism in World Politics', European Journal of International Relations, 3:3 (1997), p. 322.

${ }^{92}$ Richard Price, 'A Genealogy of the Chemical Weapons Taboo', International Organization, 49:1 (1995), p. 90.
} 
production... [of] collective action frames' that help render events meaningful and 'guide action'.93

By drawing on immanent critique grounded in the IHL principles of military necessity, proportionality, and distinction, I demonstrate how NGOs reshaped perceptions of military utility from a wide acceptance of their military necessity and effectiveness to an increasingly common view that they are outdated weapons of limited military utility. In contrast to arguments that only useless weapons or weapons of the weak have ever been banned, ${ }^{94}$ I show that assessments of military utility are closely intertwined with and shaped by the NGO campaigns for their prohibition.

In their advocacy for the bans, NGOs undertook a number of framing processes to reorient the discourse on weapons use away from being a strictly military matter of national defense. They used humanitarian 'frame amplification' 95 - highlighting the humanitarian costs of the weapons and focusing on the victims and their suffering. In addition to drawing the audience's gaze to the humanitarian side of the proportionality equation, which weighs military interests against humanitarian concerns, NGOs engaged in desecuritization and concomitant securitization replacement. However, in this case replacement does not involve conjuring up another security threat to the same referent object, but a replacement of the referent object and the threat. The referent object shifts from the state and its national security to the victims at the receiving end of violence. The weapons are no longer a defensive tool against enemies, but the enemy inflicting disproportionate harm on innocent people (often far away from Western states). Protecting those

\footnotetext{
${ }^{93}$ Robert D. Benford and David A. Snow, 'Framing Processes and Social Movements: An Overview and Assessment', Annual Review of Sociology, 26 (2000), pp. 613-14.

${ }^{94}$ David Kennedy, Of War and Law (Princeton University Press, 2006), p. 86; Rutherford, 'A Theoretical Examination of Disarming States', pp. 465-6; Price, 'Reversing the Gun Sights', p. 614; Turner, Cooper, and Pugh, 'Institutionalized and Co-Opted', p. 89.

${ }^{95}$ Benford and Snow, 'Framing Processes', p. 623.
} 
victims requires giving up the insidious weapons. Herein the security relation is inverted - the threat is the weapon, the threatened are vulnerable people around the world, but especially in the less developed countries ravaged by conflict. While the plight of the latter is politicized and placed center stage, the process is also largely depoliticized as no direct responsibility for the victims' suffering is attributed apart from the weapons themselves. The problem is the weapon rather than the ways in which it is used or those who use it. ${ }^{96}$ However, the issue is politicized again when those states unwilling to ban the weapons are accused of endangering innocent civilians by preventing the emergence of a global prohibition, irrespective of whether their current military practices cause civilian casualties. 'Responsible' use is no longer an option. Instead of some major landmine users, such as guerrilla forces, for example, the main culprit becomes the US as the superpower blocking normative progress.

Relatedly, NGO undertake issue simplification - advocating a ban as a simple and effective solution to the humanitarian problems and placing all types of landmines and cluster munitions in the same category irrespective of their design and functional differences. Thus, on the one hand, highlighting the severity and urgency of the humanitarian problems elevated the salience of the threat the weapons posed. On the other, offering an effective solution to it aimed at generating prompt action. Both processes fell within the logic of securitization.

Finally, in an attempt to address military concerns and show that they are groundless, NGOs employ what can be called 'counterframe deflation' - countering and downplaying the opponents' arguments or their 'counterframe'. To the extent that the attack on the counterframe is undertaken based on the opponents' own 'interpretive framework', ${ }^{97}$ the process approximates

\footnotetext{
${ }^{96}$ Larrinaga and Sjolander, '(Re)presenting Landmines’, p. 380; Beier, 'Dangerous Terrain’.

97 'Counterframing' denotes attempts 'to rebut, undermine, or neutralize a person's or group’s myths, versions of reality, or interpretive framework’ (Snow and Benford, 'Framing Processes’, p. 626).
} 
immanent critique. In this case, the counterframe to the humanitarian frame focused on the necessity and utility of landmines and cluster munitions. Deflating it included a double move questioning the credibility of the military regarding the evidential substantiation of their claims about the weapons' military effectiveness and at the same time enhancing the NGOs' credibility by drawing support from high-rank military figures. The latter tactic aimed at increasing the social capital of NGOs vis-à-vis the military audience ${ }^{98}$ and was employed in countries where the military strongly opposed the bans, while government officials considered supporting them.

These processes demonstrate the NGOs’ roles as (de)securitizing actors and their gaining an influential voice on military matters - something usually overlooked in securitization theory due to its focus on traditional decision-makers in positions of power. ${ }^{99}$ NGOs desecuritize national defense practices by pulling decisions about weapons use out of the domain of national security and military discretion into the open for public discussion of their humanitarian costs and impact on human beings. Thus they politicize the issue and move it into the realm of normal politics. ${ }^{100}$ At the same time, NGOs use the 'grammar of security' invoking 'existential threats' and need for urgent action. ${ }^{101}$ But they do so to portray weapons as a threat to human lives and development the opposite of the conventional 'grammar of security' in which 'our' weapons are part and parcel of state defense and community protection. ${ }^{102}$ Finally, the measures NGOs advocate are an immediate and comprehensive ban on a category of weapons rather than context-specific rules to

\footnotetext{
${ }^{98}$ On the role of different discourses aimed at different audiences during desecuritization processes, see, Salter, 'Securitization and Desecuritization'.

${ }^{99}$ Matt McDonald, 'Securitization and the Construction of Security', European Journal of International Relations, 14:4 (2008), p. 573.

${ }^{100}$ Ole Wæver, 'Securitization and Desecuritization', in Ronnie Lipschutz (ed.), On Security (Columbia University Press, 1995), pp. 46-86; Claudia Aradau, 'Security and the Democratic Scene: Desecuritization and Emancipation', Journal of International Relations and Development, 7 (2004), pp. 388-413; Hansen, 'Reconstructing Desecuritisation', p. 531.

${ }^{101}$ Buzan, Wæver, and de Wilde, Security: A New Framework, p. 25.

102 On humans as referent objects in humanitarian disasters, see, Scott Watson, 'The "Human” as Referent Object? Humanitarianism as Securitization’, Security Dialogue, 42:1 (2011), pp. 3-20.
} 
manage their use or slowly evolving regulations. It is a prioritization move calling for resources to solve a humanitarian problem, but without the vestiges of militarization often inherent in securitization. Thus, the NGOs simultaneously securitize weapons as threats, secure vulnerable human beings, desecuritize military practices, and reframe as threatening those actors that boycott the bans. The latter reframing focuses in particular on the US, which from a global guarantor of security becomes represented by NGOs as a threat to international norms and innocent victims of landmines and cluster munitions.

In addition to the discursive frames, a few factors facilitate the emergence of NGOs as authoritative speakers on a redefined security issue. As in securitization theory, these are largely related to the actors' social capital, although for NGOs it is based on different sources compared to traditional security actors. In the examined cases, they include the NGOs’ legal expertise, ${ }^{103}$ humanitarian work on the ground and moral credentials, credibility and expertise as former military soldiers who have dedicated themselves to clearing the remnants of war, and importantly, their close collaboration with diplomats in shaping the international agenda on humanitarian issues and hammering out their solutions. In a cyclical, co-constitutive process, by assuming some of the responsibility for resolving humanitarian problems, such as landmines early on, ${ }^{104}$ NGOs become authoritative players and gain a say in defining what future human security issues may be. Next, I trace the discursive processes that have been key in elevating NGOs as (de)securitizing actors.

\footnotetext{
${ }^{103}$ On legal expertise in international security, see, Anna Leander and Tanja Aalberts, 'Introduction: The CoConstitution of Legal Expertise and International Security’, Leiden Journal of International Law, 26 (2013), pp. 783-792.

${ }^{104}$ Iver B. Neumann, 'Harnessing Social Power: State Diplomacy and the Land-Mines Issue', in Andrew F. Cooper et al. (eds), Enhancing Global Governance (United Nations University Press, 2002), pp. 106-132.
} 


\section{A genealogy of weapon obsolescence}

'The landmine has often been referred to as the weapon of poor countries, of guerrilla forces...Cluster munitions are virtually the opposite - weapons of the major powers'. ${ }^{105}$

'In reality cluster munitions are mainly outdated weapons with limited military utility in modern combat'; 106 'outdated relics of the cold war'. ${ }^{107}$

A cluster munition (CM) designates a ground-launched or airdropped rocket/dispenser that 'scatter[s] widely smaller submunitions, which usually number in the dozens or hundreds' ${ }^{108} \mathrm{CMs}$ are area weapons designed to strike anything that comes within their footprint and are used against a large set of targets - troops, soft-skinned vehicles and heavy armor, anti-aircraft missile sites, enemy artillery, or airfields. Two main problems with CMs have been identified. First, they pose immediate dangers to civilians during attacks due to their inaccuracy, large numbers, and wide dispersal patterns. Second, a significant percentage of cluster submunitions fail to detonate upon impact and leave numerous unexploded duds, which when disturbed kill unsuspecting victims years after their use. ${ }^{109}$

Military utility: the conventional logic of national security

\footnotetext{
${ }^{105}$ Rae McGrath, Cluster Bombs: the Military Effectiveness and Impact on Civilians of Cluster Munitions. Landmine Action UK Report (September 2000), p. 52.

${ }^{106}$ Cluster Munition Coalition, 'Prohibiting Cluster Munitions: Summary of Key Issues’, (2007), \{http://www.minesactioncanada.org/tool_kit/more\%20info/Cluster\%20Munition\%20Coaition/en/CMC\%20key\%20i ssues\%20summary.pdf $\}$

${ }^{107}$ General Lord Ramsbotham, quoted in Landmine Action, 'Georgia: UK must condemn Russian Use of Cluster Munitions', Press release (15 August 2008), \{http://web.archive.org/web/20111104181532/http://www.landmineaction.org/resources/resource.asp?resID=1104\} ${ }^{108}$ Steve Goose, 'Cluster Munitions: Toward a Global Solution', in HRW 2004 World Report, pp. 247, $\{$ http://hrw.org/wr2k4/12.htm\#_Toc58744961\}. The Convention on Cluster Munitions defines a CM more narrowly and technically.

${ }^{109}$ Goose, 'Cluster Munitions’.
} 
The military sector represents a case of institutionalized securitization, where the grammar of security holds and issues are a priori prioritized and lifted above normal politics. ${ }^{110}$ The logic of war leads to extremes where nothing is off-limits to ensure national survival. ${ }^{111}$ The military defends the state against external threats using the weapons and techniques at its disposal. Once war starts, it gets to decide which weapons are to be used to prevail in the fight. The military is sealed off from public scrutiny and weapons are chosen based on the military's assessment of their military uses and utility.

Thus, prior to the campaigns against landmines and CMs, the necessity and utility of those weapons remained a military matter alone to be decided by the logic of security. Even a few months before the launch of negotiations for the prohibition of $\mathrm{CMs},{ }^{112}$ there was common agreement about their high military utility, which was perceived as an obstacle to restricting their use, let alone banning them outright. ${ }^{113}$

Over time, the military has valued the military effectiveness of CMs and this remained a cornerstone of their opposition to a ban. For example, US military officers in Vietnam expected that 'these weapons could give [them] a quantum leap on the enemy'. ${ }^{114}$ During the 1991 Gulf War, CMs were portrayed as 'the decisive battle winner', ${ }^{115}$ while battle damage assessments of the 1999 Kosovo campaign claimed it 'demonstrated the importance' of CBU-87 cluster bombs

\footnotetext{
${ }^{110}$ Buzan, Wæver and de Wilde, Security: A New Framework, pp. 27-28.

${ }^{111}$ Wæver, 'Securitization and Desecuritization', p. 54.

112 The so-called Oslo Process to ban CMs was launched by Norway in February 2007 after states had been discussing the issue for several years within the forum of the Convention on Certain Conventional Weapons. See, John Borrie, Unacceptable Harm: A History of How the Treaty to Ban Cluster Munitions Was Won (UNIDIR, 2009).

${ }^{113}$ Interviews 20031210; 20060330; 20060511.

${ }^{114}$ Michael Krepon, 'Weapons Potentially Inhumane: The Case of Cluster Bombs’, Foreign Affairs (April 1974), p. 599.

115 'M26 Multiple Launch Rocket System', \{http://www.globalsecurity.org/military/systems/munitions/m26.htm\}; Colin King, Explosive Remnants of War: A Study on Submunitions and Other Unexploded Ordnance. ICRC Report (August 2000), p. 17.
} 
despite the unexploded-ordnance hazard associated with them. ${ }^{116}$ The newest sensor-fuzed, antiarmor cluster bombs were equally praised after their debut in $2003 .{ }^{117}$ And yet, all of these weapons were banned in 2008.

Government officials have similarly maintained the indispensability and high effectiveness of CMs. In 2005, UK representatives at the Convention on Certain Conventional Weapons (CCW) argued:

Cluster munitions are still the most appropriate air-delivered weapons in many situations... The area effect capability of air-dropped cluster munitions is not matched by current precision weapons... Artillery-launched cluster munitions will maintain a crucial capacity in the suppression of area targets for a long time to come. ${ }^{118}$

And in 2007, eight months into the negotiations of the Oslo Process to ban CMs, the UK government still deemed that a CM prohibition would 'adversely impact on the UK's operational effectiveness [and] impose serious capability gaps on our Armed Forces'. ${ }^{119}$ Similarly, according to French officials, CMs remained 'of unrivalled efficiency' for 'the neutralization of ground targets (vehicles, artillery batteries, temporary battlefield supply points, etc.)', ${ }^{120}$ and 'to decide to

\footnotetext{
${ }^{116}$ US Department of Defense, Kosovo/Operation Allied Force After Action Report. Report to Congress (31 January 2000), p. 90.

${ }^{117}$ Chris Stockton, 'A Debut with a Bang', Precision Strike Digest, 16:5 (2003), pp. 6-7.

118 'Military Utility of Cluster Munitions', Working paper prepared by the UK, Group of Governmental Experts of The Parties To The CCW, Working Group on Explosive Remnants of War, CCW/GGE/X/WG.1/WP.1 (21 February 2005).

119 'Reports from the Defence, Foreign Affairs, International Development and Trade and Industry Committees, Presented to Parliament by the Secretaries of State for Defence, Foreign and Commonwealth Affairs, International Development and Business, Enterprise and Regulatory Reform by Command of Her Majesty' (November 2007), \{https://www.gov.uk/government/uploads/system/uploads/attachment_data/file/243149/7260.pdf\}.

${ }^{120}$ France, 'Technical Improvements to Submunitions', Working paper CCW/GGE/II/WP.6, Group of Governmental Experts of The Parties to the CCW (10 July 2002), p. 1.
} 
dispense with them would mean to accept an important reduction of states' land defense capabilities, and of France, in particular' ${ }^{121}$ Throughout the period, US state and military officials have also vigorously asserted that CMs 'serve indispensable military purposes', 'provide distinct advantages... and can result in less collateral damage than unitary bombs’. ${ }^{122}$

These assumptions were widespread beyond state officials. An independent munition expert, argued that, '[t]he trend towards increasing use of submunitions seems unlikely to change in the foreseeable future. From a military point of view, they offer unmatched cost-effectiveness in their ability to dispense a payload over a broad area and attack multiple targets' ${ }^{123}$ According to another expert, cluster weapons were even a 'battle winning munition' ${ }^{124}$ In 2007, experts still observed that 'there is clearly a military role for cluster munitions and one could not ask the military to carry out missions with one hand tied behind its back’. ${ }^{125}$

Hence, initially NGOs saw the military utility of CMs as an obstacle on the way of any regulations they were advocating. Even the few NGO reports that probed the military effectiveness of CMs did not reject it altogether. A Landmine Action report argued that in a number of examined conflicts CMs had not been a 'critical positive combat factor for the user force', but still '[w]hen the cluster munition works, it works. If it were possible to manufacture a variant with no propensity

\footnotetext{
121 'La position française sur les sous-munitions - Intervention du Général Scellos (en tant que représentant du ministère de la Défense)', Colloque au Sénat (6 October 2005),

\{http://web.archive.org/web/20071014030042/http://www.sousmunitions.fr/fileadmin/images/actualites/Intervention GBSCELLOS.pdf\}. My translation, the original reads, 'Décider de s'en passer impliquerait d'accepter une réduction importante des capacités de défense terrestre des Etats en général et de la France en particulier'.

${ }^{122}$ Statement of Edward Cummings, Head of the US Delegation to the Second Preparatory Conference of the 2001 CCW Review Conference (5 April 2001). Also, US Department of Defense, Defense Science Board Task Force on Munitions System Reliability. Report (September 2005), p. 11; Robert M. Gates, 'Memorandum for the Secretaries of the Military Departments. Subject DoD Policy on Cluster Munitions and Unintended Harm to Civilians' (19 June 2008).

${ }^{123}$ King, Explosive Remnants, p. 37. Whereas the assessment of CM effectiveness in different conflicts varied, in the 1991 Gulf War their military utility was 'clear' (ibid, p. 17).

${ }^{124}$ Quoted in Pax Christi Netherlands, Cluster Weapons: Necessity or Convenience? Report (June 2005), p. 20, \{https://www.paxvoorvrede.nl/media/files/cluster-weapons-necessity-or-convenience.pdf\}.

${ }^{125}$ ICRC, Humanitarian, Military, Technical, and Legal Challenges of Cluster Munitions. Report of the Montreux Expert Meeting (18-20 April 2007), p. 19.
} 
for failure and causing long-term danger, the military effectiveness of cluster munitions would not be in question'. ${ }^{126}$ Another report posed questions about the battle effects of CMs, but acknowledged that, '[t]here is no doubt about the military utility of cluster weapons against large mechanized forces, especially those attacking or on the move' and they were 'certainly not "out of fashion” even in advanced Western forces' ${ }^{127}$ Even when the international campaign to ban CMs was picking up momentum in mid-2006, a former NGO researcher espoused the predominant view that, 'unlike anti-personnel mines, the military utility of these weapons is more readily and widely recognized'. ${ }^{128}$

However, this statement read the past from the present. At the time when the landmine campaign was launched, the perceived military utility of landmines was much higher than in the 2000s. As I argue, common views about their low military significance today are in no small measure the result of the campaign for their prohibition itself. ${ }^{129}$ For example, in January 1994, about a year after the establishment of the International Campaign to Ban Landmines (ICBL), the International Committee of the Red Cross (ICRC) convened an expert meeting that concluded that the prevailing view was that the military utility of landmines warranted their continued use and the military did not regard alternative systems to be viable. ${ }^{130}$ Similarly, in February 1994, a NGO representative underlined that, '[t]he landmine is a weapon of great utility to the military, both to the high-level strategists, the planners of war, and to the individual soldier, who sees the mine as

\footnotetext{
126 McGrath, Cluster Bombs, p. 52.

${ }^{127}$ Pax Christi Netherlands, Cluster Weapons, pp. 22, 25.

${ }^{128}$ Rosy Cave, 'Disarmament as Humanitarian Action? Comparing negotiations on anti-personnel mines and explosive remnants of war', in John Borrie and V. Martin Randin (eds), Disarmament as Humanitarian Action: From Perspective to Practice (UNDIR, June 2006), p. 62.

129 Also, Price, 'Reversing the Gun Sights'.

${ }^{130}$ ICRC, 'Report of the ICRC for the review conference of the 1980 UN conventions on Prohibitions or restrictions on the use of certain conventional weapons which may be deemed to be excessively injurious or to have indiscriminate effects', International Review of the Red Cross, 299 (1994), pp. 123-182.
} 
personal protection and a flexible offensive weapon' ${ }^{131}$ In 1995, military considerations still dominated state discussions on restricting landmines at the CCW Review Conference. ${ }^{132}$ The US military extolled the contribution of mines to the US victory in the 1991 Gulf War, insisting that the weapons were an 'indispensable' element of maneuver warfare and 'will be required by US forces for safe defense in the foreseeable future'. ${ }^{133}$ And not only did the US military hold such views. The defense ministries of Sweden and Finland insisted that landmines were an essential element of their territorial defense. In 1996, the ICRC still observed that there was 'the assumption that [antipersonnel mines] are an essential weapon of high military value and that their military value outweighs their human cost', which hindered progress toward a prohibition despite concern over the humanitarian crisis. ${ }^{134}$

Another argument the military employed emphasized the role of the weapons in protecting soldiers' lives. This was particularly salient in the landmine case when the Pentagon projected against the humanitarian frame 'the image of a U.S. soldier pinned down in a foxhole but protected by mines' ${ }^{135}$ Despite the fact that CMs do not serve predominantly defensive purposes, they too were portrayed as important for force protection. UK representatives argued that, if precisionguided munitions were used instead of CMs against moving targets in wide areas, that would necessitate multiple attacks, 'be inefficient and would significantly increase the risk to the delivery

131 “'Safe-Mines” and Submunitions,' in ICBL, Second NGO Conference on Landmines Final Report, Geneva (9-11 May 1994).

132 'Summary Record of the $6^{\text {th }}$ Meeting', the Austria Center Vienna, 28 September 1995. Review Conference of the States Parties to the CCW, CCW/CONF.I/SR.6 (5 October 1995), p. 4.

${ }^{133}$ Letter by John M. Shalikashvili, Chairman of the Joint Chiefs of Staff to Hon. Floyd Spence, Chairman, Committee on National Security, House of Representatives. Congressional Record: H14787-H14796 (13 December 1995).

${ }^{134}$ ICRC, Anti-personnel Landmines - Friend or Foe?: A Study of the Military Use and Effectiveness of AntiPersonnel Mines (March 1996), p. 5.

${ }^{135}$ Center for International Policy, 'Commander-in-Chief: Contrasting the Presidential Roles in the World Campaigns to Ban Chemical Weapons (1919-45) and Land Mines (1990s)', Report (1999),

\{http://web.archive.org/web/20030627124754/http://ciponline.org/oldiprcomm.htm\} 
aircraft'. ${ }^{136}$ In 2007, it was still maintained that a ban would 'take away one element of force protection'. ${ }^{137}$ Similarly, the US envisioned future scenarios when 'the massed use of conventional munitions for force protection' would be needed, although it recognized the threat unexploded submunitions posed to their own soldiers. ${ }^{138}$

Finally, the military insisted that the weapons could be used in discriminate and proportionate ways and technological fixes would resolve their reliability problems. 'Smart' mines and CMs, which self-destruct and self-deactivate, were touted as the solution ensuring both military effectiveness and civilian protection. ${ }^{139}$

From military utility to humanitarian harm: protecting civilians and politicizing weapons use

Thus, at the outset, landmine and CM campaigners faced overwhelming opposition and widespread, ingrained perceptions about the military utility of the weapons. As widely recognized, the main NGO strategy to overcome this opposition was to create a discourse highlighting the civilian suffering those weapons caused. ${ }^{140}$ This was the humanitarian 'frame amplification', which exemplifies a process of desecuritizing the issue by moving it from the field of state security

\footnotetext{
136 'Military Utility of Cluster Munitions’, CCW/GGE/X/WG.1/WP.1 (21 February 2005), p. 2.

137 'Reports from the Defence, Foreign Affairs, International Development and Trade and Industry Committees', p. 35.

${ }^{138}$ US Department of Defense, Munitions System Reliability, p. 38.

139 'Military Utility of Cluster Munitions', CCW/GGE/X/WG.1/WP.1; US Department of Defense, Munitions System Reliability.

140 Jody Williams and Stephen Goose, 'The International Campaign to Ban Landmines', in Maxwell A. Cameron et al. (eds), To Walk Without Fear (Oxford University Press, 1998), pp. 20-47; Price, 'Reversing the Gun Sights'; Larrinaga and Sjolander, ‘(Re)presenting Landmines’; Rutherford, 'Evolving Arms Control’; Hubert, 'The Landmine Ban’.
} 
where the military has the upper hand into the field of human security, humanitarian aid, and development where it can be publicly discussed and where NGOs assume key roles.

The humanitarian frame amplification started with awareness-raising by gathering evidence on the magnitude of the problems the weapons caused. In the case of landmines, NGOs started documenting the scale of landmine contamination in different parts of the world and its impact on civilians and their way of living, which resulted in a series of influential reports. ${ }^{141}$ The emerging narrative drew up a picture of a new, urgent security threat to a new referent object vulnerable people around the world, be they farmers, innocent children, or NGO members carrying out humanitarian work. From defenders of national borders and embattled soldiers, landmines became the enemy of innocent people around the world. ${ }^{142}$ Furthermore, landmines had turned into a 'crisis' and 'humanitarian disaster', ${ }^{143}$ a 'global epidemic', ${ }^{144}$ likened to 'weapons of mass destruction in slow motion'. ${ }^{145}$ The image was powerful and even the US State Department agreed that, 'landmines may be the most toxic and widespread pollution facing mankind'. ${ }^{146}$ In amplifying the humanitarian harm and the need to urgently address it, NGOs argued that 26,000 people fell

\footnotetext{
${ }^{141}$ Human Rights Watch (HRW) and Physicians for Human Rights (PHR), Land Mines in Cambodia: The Coward's War (September 1991); HRW, Hidden Death: Land Mines and Civilian Casualties in Iraqi Kurdistan (October 1992); PHR, Hidden Enemies: Land Mines in Northern Somalia (November 1992); HRW, Land Mines in Angola (February 1993); HRW and PHR, Landmines: A Deadly Legacy (October 1993); African Rights and Mines Advisory Group, Violent Deeds Live On: Landmines in Somalia and Somaliland (December 1993); HRW, Landmines in Mozambique (February 1994); Shawn Roberts and Jody Williams, After the Guns Fall Silent: The Enduring Legacy of Landmines (Vietnam Veterans of America Foundation, 1995).

${ }^{142}$ Larrinaga and Sjolander, '(Re)presenting Landmines'.

${ }^{143}$ Boutros Boutros-Ghali, ‘The Land Mine Crisis: A Humanitarian Disaster’, Foreign Affairs, 73:5 (1994), pp. 813; HRW and PHR, Landmines: A Deadly Legacy.

${ }^{144}$ ICBL, Second NGO Conference on Landmines. Final Report (9-11 May 1994), p. 13.

${ }^{145}$ HRW and PHR, Landmines: A Deadly Legacy, pp. 3, 355.

${ }^{146}$ Hidden Killers: The Global Problem with Uncleared Landmines, quoted in Congressional Record, Senate (28 February 1994).
} 
victim to mines each year, counted their mounting numbers as time passed without an international agreement on a ban, and emphasized that millions of mines still remained in the ground. ${ }^{147}$

The lawfulness of military force under IHL is regulated by two core principles: always making a distinction between civilians and soldiers and only targeting the latter (the distinction principle) ${ }^{148}$ and ensuring that the unintended negative effects on innocent bystanders do not exceed the military advantages sought by an attack (the proportionality principle). ${ }^{149}$ The proportionality principle is rather vague and difficult to apply, which has led to criticisms that it privileges military necessity over humanitarian concerns ${ }^{150}$ and is often used to justify excessive force. ${ }^{151}$ Nevertheless, I argue that it contains within it the ideal of civilian protection and has been used to challenge military practices. Based on the above two IHL principles, ${ }^{152}$ NGOs argued that given their long-term effects, landmines were indiscriminate weapons that could not distinguish between civilians and soldiers. Importantly, starting from the proportionality principle, they have

${ }^{147}$ ICBL, Report on Activities: Review Conference of the Convention on Conventional Weapons, Geneva (22 April-3 May 1996), p. 42. NGOs not only amplified, but may have also inflated the number of casualties and the proportions of the crisis; Larrinaga and Sjolander, '(Re)presenting Landmines', pp. 374-7.

148 The principle is codified in Art. 51(1-4) of the 1977 Protocol I Additional to the Geneva Conventions. It states that 'The civilian population and individual civilians shall enjoy general protection against dangers arising from military operations', 'shall not be the object of attack', and indiscriminate attacks 'of a nature to strike military objectives and civilians or civilian objects without distinction’ are prohibited.

${ }^{149}$ The principle is codified in Art. 51(5)(b) of 1977 Protocol I Additional to the Geneva Conventions, which prohibits 'an attack which may be expected to cause incidental loss of civilian life, injury to civilians, damage to civilian objects, or a combination thereof, which would be excessive in relation to the concrete and direct military advantage anticipated'.

${ }^{150}$ Judith Gail Gardam, 'Proportionality and Force in International Law', American Journal of International Law, 87:3 (1993), pp. 407, 409; Dale Stephens and Michael W. Lewis, 'The Law of Armed Conflict - A Contemporary Critique', Melbourne Journal of International Law, 6 (2005), p. 76.

${ }^{151}$ Michael Walzer, 'Responsibility and Proportionality in State and Nonstate Wars', Parameters, 39:1 (2009), pp. 40-52.

${ }^{152}$ A third relevant principle is a prohibition 'to employ weapons, projectiles and material and methods of warfare of a nature to cause superfluous injury or unnecessary suffering'; Art. 35(2), Protocol I Additional to the Geneva Conventions of 12 August 1949, and relating to the Protection of Victims of International Armed Conflicts (8 June 1977). The principle is tied to the idea that only violence that is militarily necessary can be inflicted upon combatants. This principle informed the discussion on weapons restrictions in the 1970s and some of ICRC's early work in the 1990s on landmines as causing severe and cruel injuries. However, given that this principle regards mostly violence against combatants, for the most part the ICBL did not base NGO arguments on it. 
insisted that whatever their military utility, it was far outweighed by their grave and wide-ranging humanitarian effects on civilians. ${ }^{153}$

Similarly, regarding CMs NGOs gathered data on the numbers of civilian casualties and the socio-economic costs of their use in all conflicts starting with the NATO intervention in Kosovo in 1999. ${ }^{154}$ They provided information about the submunition failure rates in actual combat to show that manufacturer and military claims about munition reliability were misleading and the high percentages of unexploded submunitions left on the ground in the wake of hostilities turned them into de facto landmines. Although the CM problem was considerably smaller than that of landmines, in line with the securitization logic, NGOs sought to amplify its severity and sense of urgency by alluding to a 'humanitarian crisis in the waiting', a 'looming disaster' unless prompt actions were taken to avert it. ${ }^{155}$

\footnotetext{
${ }^{153}$ E.g., ICBL, Report on Activities: Review Conference of the Convention on Conventional Weapons. Vienna, Austria (25 September-13 October 1995), p. 35; ICBL, The Human and Socio-Economic Impact of Landmines: Toward an International Ban. Final Report of the Landmine Conference, Phnom Penh (1995); ICBL, 'NGOs Criticize Lack of Progress at UN Weapons Conference in Vienna', ICBL Press Release (6 October 1995); ICRC, Friend or Foe; Jody Williams, 'Landmines and Measures to Eliminate Them', International Review of the Red Cross, 307 (1995), pp. 375-390.

${ }^{154}$ E.g., HRW, Ticking Times Bombs: NATO’s Use of Cluster Munitions in Yugoslavia. Report (June 1999), \{http://www.hrw.org/reports/1999/nato2/\}; HRW, Civilian Deaths in the NATO Air Campaign. Repport (February 2000), \{http://www.hrw.org/reports/2000/nato/\}; HRW, Fatally Flawed: Cluster Bombs and their Use by the United States In Afghanistan, Report (December 2002); HRW, Off Target: The Conduct of the War and Civilian Casualties in Iraq. Report (December 2003); HRW, Flooding South Lebanon: Israel's Use of Cluster Munitions in Lebanon in July and August 2006. Report (February 2008); Mennonite Central Committee, Cluster Bomb Use in the Yugoslavia/Kosovo War. Report (1999); Mennonite Central Committee, Clusters of Death: The Mennonite Central Committee Global Report on Cluster Bomb Production and Use (2000); McGrath, Cluster Bombs; King, Explosive Remnants of War. ICRC Report (August 2000); Landmine Action, Foreseeable Harm. The Use and Impact of Cluster Munitions in Lebanon: 2006. Report (October 2006); Richard Moyes, Cluster Munitions in Kosovo: Analysis of Use, Contamination, and Casualties, Landmine Action Report, (February 2007); Handicap International, Circle of Impact: the Fatal Footprint of Cluster Munitions on People and Communities. Report (May 2007); Norwegian People's Aid, Yellow Killers: The Impact of Cluster Munitions in Serbia and Montenegro. Report (2007).

${ }^{155}$ HRW, 'Convention on Conventional Weapons (CCW): Time to Begin a New International Instrument on Cluster Munitions. Statement at the $3^{\text {rd }}$ Review Conference', (8 November 2006), \{http://hrw.org/english/docs/2006/11/08/global14535.htm\}; Landmine Action, 'Opening Statement by Simon Conway’, 3rd CCW Review Conference (8 November 2006).
} 
Where the military asserted responsible and proportionate use of the weapons and the manufacturers touted high reliability rates, NGOs showed that neither of those claims held in practice. Human Rights Watch (HRW) questioned the proportionality of CMs following the Kosovo intervention, arguing that 'the long-term harm to the civilian population of cluster bomb use may outweigh the short-term military benefit'. ${ }^{156}$ It emphasized that due to their wide-area coverage and unexploded remnants, use of CMs 'in or near populated areas is almost always disproportionate,... because of the harm their duds inflict on civilians over time relative to the military advantage sought' ${ }^{157}$ Moreover, NGOs argued that military claims of proportionate use were groundless when the humanitarian side of the balance was not seriously taken into account. ${ }^{158}$ In addition to marshalling statistics about the numbers of landmines and unexploded submunitions, their failure rates, and numbers of casualties around the world, NGOs focused attention on the human face of the victims and the horrendous marks the weapons had left on their bodies and lives. ${ }^{159}$ NGOs highlighted the suffering of innocent victims, especially women and children, ${ }^{160}$ while survivors were brought to participate in the negotiations to both empower them and remind state delegates of the human faces behind the statistics. ${ }^{161}$ This imparted emotional

\footnotetext{
${ }^{156}$ HRW, Fatally Flawed: Cluster Bombs and Their Use by the United States in Afghanistan, Report (December 2002), p. 30.

${ }^{157}$ HRW, 'Cluster Munitions and the Proportionality Test', Memorandum to Delegates of the Convention on Conventional Weapons (April 2008), p. 3.

158 Brian Rappert, Out of Balance: The UK Government's Efforts to Understand Cluster Munitions and International Humanitarian Law (Landmine Action Report, November 2005).

${ }^{159}$ Rutherford, ‘Evolving Arms Control’; John Borrie, Unacceptable Harm, pp. 180-1.

${ }^{160}$ Although the estimates were that women and children comprised about 30 , maximum $40 \%$ of the landmine victims, the NGOs have always emphasized them and occasionally claimed they made $90 \%$ of the victims (Larrinaga and Sjolander, '(Re)presenting Landmines', pp. 376-7).

${ }^{161}$ E.g., Handicap International's project 'Ban Advocates' aimed at providing a voice for the victims of CMs and actively engaged them in lobbying activities during the negotiations (www.banadvocates.org).
} 
power to the NGOs arguments ${ }^{162}$ and singled out the weapons as problematic by linking them directly to the human suffering and bodily mutilations they had caused. ${ }^{163}$

From a political and a legal point of view, amplifying the humanitarian impact of the weapons shifts estimates of the balance between military interests and humanitarian costs, even if one assumes that perceptions of military utility remain constant. Thus, the principle of proportionality opened an opportunity for NGOs to challenge military arguments. However, relying on the strictly legal principles was insufficient to achieve a prohibition and NGOs turned to a more flexible political frame to mobilize support for a ban among the public and overcome state resistance. In the CM case, the Oslo negotiation process was based on the understanding that states had gathered to ban those CMs that caused 'unacceptable harm on civilians' ${ }^{164}$ and whose 'humanitarian and political consequences - long after the conflicts have ended - by far outweigh their usefulness' ${ }^{165}$ Thus from their inception, the negotiations were embedded in a humanitarian frame. By providing evidence that even advanced submunitions, advertised as leaving only 1-2\% duds, did not function properly and led to civilian casualties in recent conflicts, such as the war in Lebanon in 2006, NGOs were effectively showing that such weapons did cause 'unacceptable harm' and the 'smart' technical solutions to the humanitarian problem advocated by the military were unfeasible. By framing the issue in humanitarian terms, they placed the burden of proof that

\footnotetext{
${ }^{162}$ See, Stan Brabant, 'The Ban Advocates: Cluster Munition Victims' Commitment to the Implementation of the Convention on Cluster Munitions', Disarmament Forum 1 (2010), pp. 3-12.

${ }^{163}$ It has been argued that norms about preventing bodily harm to innocent people have particular resonance internationally. See, Martha Finnemore and Kathryn Sikkink, 'International Norm Dynamics and Political Change', International Organization, 52: 4 (1998), pp. 887-917; Margaret E. Keck and Kathryn Sikkink, Activists beyond Borders: Advocacy Networks in International Politics, (Cornell University Press, 1998).

${ }^{164}$ Norwegian Ministry of Foreign Affairs, 'Invitation Letter to the Oslo Conference by Jonas Gahr Støre’ (December 2006), \{http://www.clusterconvention.org/files/2012/12/CCW-Invitation-letter.pdf \}

165 Jonas Gahr Støre, 'Opening Statement by Minister of Foreign Affairs', Oslo Conference on Cluster Munitions, Oslo, (22 February 2007).
} 
certain weapon systems work properly and provide significant military utility on the shoulders of those claiming so. ${ }^{166}$

However, not only have NGOs moved the debate from a security to a humanitarian plane, as most authors have noticed. ${ }^{167}$ They have also consciously sought to undermine arguments about the military utility of the weapons in a process of 'counterframe deflation' - something largely neglected in scholarly work on the landmine campaign. ${ }^{168}$

From military utility to obsolescence: desecuritizing national defense

Early in the landmine campaign, campaigners argued that the 'armed forces will not respond to the emotional issue' of human suffering and thus it was 'necessary to present a coherent response to each of the arguments raised by military' and 'make a serious effort to question the military usefulness of landmines'. ${ }^{169}$ The idea was to 'challenge the claim of military necessity, and distinguish between military necessity and more limited military utility'. ${ }^{170}$ This desecuritization move sought to show that the solution to the military problem did not work and could not contribute to military goal achievement and national security. Engaging the military on its own argumentative grounds also represented immanent critique in practice.

\footnotetext{
${ }^{166}$ Price, 'Reversing the Gun Sights'; Rappert, Out of Balance; Brian Rappert and Richard Moyes, 'The Prohibition of Cluster Munitions: Setting International Precedents for Defining Inhumanity’, Nonproliferation Review, 16:2 (2009), pp. 237-56.

${ }^{167}$ Rutherford, 'Evolving Arms Control'; Price, 'Reversing the Gun Sights'; Larrinaga and Sjolander, '(Re)presenting Landmines'; Hubert, 'The Landmine Ban’.

168 Price, 'Reversing the Gun Sights', pp. 632-33 is a notable exception.

169 ICBL, Second NGO Conference on Landmines. Final Report (9-11 May 1994), p. 82.

${ }^{170}$ ICBL, Second NGO Conference on Landmines, p. 83.
} 
The landmine campaign was helped in this regard by a 1994 report of the Institute for Defense Analysis. It argued that landmines had utility in defensive operations, whereas future US campaigns were most likely to be offensive, and outlined some very stringent conditions under which antipersonnel landmines would have an effect, concluding that 'military utility in high intensity conflict need not preclude consideration of landmine arms control' ${ }^{171}$ The report provided substantive grounds for NGOs to claim that the military utility of landmines had been highly exaggerated, ${ }^{172}$ point out differences of military opinion on the matter, and assert that mines were neither 'essential' nor 'indispensable.' ${ }^{173}$ From there some activists went on to argue that mines were 'just another form of old-fashioned ill-conceived weapon[s] set to disappear from regular warfare’. 174

They were also portrayed as cheap weapons for poor countries that did not yield any relative advantage to the US, whose soldiers oftentimes fell victim to landmines in war and peace operations. $^{175}$

In 1996, the ICRC commissioned a study of the military effectiveness of landmines in conflicts starting with WWII and later convened a meeting with military experts to discuss its

\footnotetext{
${ }^{171}$ Stephen D. Biddle, Julia L. Klare, and Jaeson Rosenfeld, The Military Utility of Landmines: Implications for Arms Control, IDA Document D-1559 (1994), p. 68.

${ }^{172}$ CCW News, 'What are we doing here' (11 October 1995), in ICBL, Report on Activities: Review Conference of the Convention on Conventional Weapons, Vienna, Austria (25 September - 13 October 1995); 'Summary Record of the $6^{\text {th }}$ Meeting', the Austria Center Vienna, 28 September 1995. Review Conference of the States Parties to the Convention on Prohibitions or Restrictions on the Use of Certain Conventional Weapons Which May Be Deemed to Be Excessively Injurious or to Have Indiscriminate Effects, CCW /CONF.I/SR.6 (5 October 1995), p. 6.

${ }^{173}$ ICBL, Human and Socio-Economic Impact of Landmines, p. 56.

${ }^{174}$ Jef Van Gerwen, ‘Anti-Personnel Landmines: An Ethical Reflection’, The Month (May 1995), reprinted in ICBL, Human and Socio-Economic Impact of Landmines.

${ }^{175}$ ICRC, Friend or Foe, pp. 45-47; ICBL, ‘CCW - Trading Away People’s Lives’, Press Release (October 1995), in ICBL, Report on Activities, Vienna, Austria (25 September-13 October 1995); New York Times, 'Stop Stalling on Land Mines' (26 August 1997), New York Times, 'Failures of Leadership on Land Mines’ (21 June 1997); Frederick Downs Jr., '100 Million Land Mines; A Soldier's Plea to Ban the Weapon That Kills Civilians Every Day', Washington Post (21 April 1996); Dana Priest, 'U.S. Holds Key to Ban Of Mines', Washington Post (2 January 1997).
} 
findings. Its unanimous conclusion was that, '[t]he limited military utility of AP [antipersonnel] mines is far outweighed by the appalling humanitarian consequences of their use in actual conflicts', ${ }^{176}$ a position subsequently endorsed by 55 senior military commanders from 19 countries.

Questioning the military use of weapons was key in the US campaign to ban landmines. In what is considered a particularly important campaign tactic, ${ }^{177}$ the Vietnam Veterans of America Foundation convinced 15 high-ranking retired generals to sign an open letter to President Clinton assuring him that banning landmines was 'not only humane, but also militarily responsible' and would not 'undermine the military effectiveness or safety of [US] forces' as it would leave 'unimpaired the use of... undeniably militarily useful weapons'.${ }^{178}$

Though they failed to convince the US to join the ban, US campaigners continued to emphasize that the landmines' limited military utility was not an obstacle to signing the treaty. As the Pentagon was preparing its recommendations for the Bush Administration's landmine policy review, HRW debunked military arguments and urged policy-makers to consider what the real military utility of landmines was. ${ }^{179}$ In December 2001, 124 congressmen sent a letter to President Bush emphasizing 'the need for the elimination of this outmoded, indiscriminate weapon from the U.S. arsenal'. ${ }^{180}$ Finally, eight generals and admirals sent another letter arguing that landmines 'are outmoded weapons that have, time and again, proved to be a liability to our own troops... the

\footnotetext{
${ }^{176}$ ICRC, Anti-personnel Landmines - Friend or Foe, p. 73.

${ }^{177}$ Mary Wareham, 'Rhetoric and Policy Realities in the United States', in Maxwell A. Cameron et al. (eds), To Walk without Fear (Oxford University Press, 1998), p. 224.

${ }^{178}$ Open letter to Clinton in the New York Times (3 April 1996), reproduced in Congressional Record, House (15 May 1997), pp. H2776-H2778, \{https://www.congress.gov/crec/1997/05/15/CREC-1997-05-15-pt1-PgH2776.pdf . ${ }^{179}$ HRW, 'Memorandum for U.S. Policymakers on Landmines' (November 2001), \{http://www.hrw.org/press/2001/11/usamines.htm\}.

${ }^{180}$ Quoted in Friends Committee on National Legislation, 'Chronology of U.S. Policy and International Mine Ban Treaty Events',

\{http://web.archive.org/web/20030828201244/http://www.fcnl.org/issues/item.php?item_id=396\&issue_id=9\}.
} 
military, diplomatic, and humanitarian advantages of speedy US accession [to the Mine Ban Treaty] far outweigh the minimal military utility of these weapons'. ${ }^{181}$

Thus, by garnering the support of military officers for their cause, NGOs tried to enhance their credibility and influence in military matters, while slowly eating away at military arguments about the unquestionable need for landmines.

A similar process of challenging and redefining the existing perceptions of military utility took place in the case of CMs, although there was a nuance in the NGO arguments. Whereas the military effectiveness of the weapons was still challenged, often this was coupled with an argument that CM use undermined the larger political goals of military campaigns to 'win the hearts and minds' of local people. Hence, the high political cost of CMs diminished their military utility. The military sector could not be viewed in isolation from the political domain.

NGOs depicted CMs as relics of the past designed for the battlefields of the Cold War rather than today’s conflicts that oftentimes took place in urban environments. As with landmines, they highlighted the heavy toll unexploded cluster submunitions took on friendly forces - exactly the opposite of the picture of the weapons' role in force protection that the military painted. ${ }^{182}$ More specifically, they questioned the piercing effects of some submunition types against contemporary tank armor, ${ }^{183}$ and importantly, pointed out the lack of studies of the military utility of CMs, which made balancing military advantages versus humanitarian costs impossible. ${ }^{184}$

\footnotetext{
${ }^{181}$ Quoted in US Campaign to Ban Landmines, 'Letter to President George W. Bush’ (17 January 2003), \{http://web.archive.org/web/20040608075606/http://www.uscbl.org:80/\}.

${ }^{182}$ HRW, 'Myths and Realities about Cluster Munitions', Campaign document (February 2007), \{www.hrw.org/campaigns/clusters/myths0307/\}. HRW stressed that in the $3^{\text {rd }}$ Infantry Division's lessons learned CMs were called 'losers' and 'a Cold war relic' due to the high failure rate of DPICM submunitions used in the 2003 Iraq War (HRW, Off Target, p. 114).

${ }^{183}$ McGrath, Cluster Bombs; Rappert, Out of Balance; Simon Conway, 'Speaker's Summary: Cluster Munitions: Historical Overview of Use and Human Impact', in ICRC, Humanitarian, Military, Technical, and Legal Challenges of Cluster Munitions. Report of the Montreux Expert Meeting (18-20 April 2007).

${ }^{184}$ Rappert, Out of Balance.
} 
Questioning the military utility of CMs became part of the strategy to delegitimize them, though secondary to the main focus on humanitarian impact. After NGOs had highlighted the humanitarian and political costs of these weapons and the momentum for a ban was growing, studies of the weapons' military utility were undertaken in order to convince the military that a ban was also militarily practicable. As in the landmine case, ${ }^{185}$ this meant countering suggestions that ban proponents were pacifists on a crusade to abolish all weapons and arguing that they were responsible statesmen giving due consideration to military interests. The tactic represented critique from within, based on military thinking, and was undertaken mostly in countries where military opposition to a ban was strong. Once again this shows that the absence of military utility was not an established fact in military circles and even less so was it a moving force behind efforts for the weapons' prohibition.

When the stand-alone Oslo Process to negotiate a treaty banning CMs started in 2007, its organizers sought to show that the CM prohibition would not compromise key military capabilities. Whereas the US did not take part in the negotiations and the domestic NGO campaign there was weak, challenging the military utility of CMs became part of the campaign in the UK, the major military force half-heartedly participating in the Oslo Process. Landmine Action led the campaign and worked with parliamentarians to pressure the government to unequivocally support the ban process. ${ }^{186}$ Campaigners portrayed CMs as 'outdated relics of the Cold War' of 'no real military gain' ${ }^{187}$ while in the UK House of Lords parliamentarians argued that CMs had no

\footnotetext{
185 Price, 'Reversing the Gun Sights', p. 632.

186 On the UK CM case, see, Margarita H. Petrova, 'Rhetorical Entrapment and Normative Enticement: How the United Kingdom Turned from Spoiler into Champion of the Cluster Munition Ban’, International Studies Quarterly, 60:3 (2016), pp. 387-399.

${ }^{187}$ Landmine Action, 'UK Signs of for Final Stage of Cluster Bomb Ban’, (22 February 2008), \{http://www.landmineaction.org/resources/resource.asp?resID=1088\}; Landmine Action, 'Georgia: UK must condemn'; Richard Norton-Taylor, 'UK ready to scrap killer cluster bombs’, Guardian (28 May 2008); Oxfam, 'Defence Secretary Must Halt Future Cluster Bomb Deaths and Injuries’ (22 April 2008), \{http://www.oxfam.org.uk/applications/blogs/scotland/2008/04/defence_secretary_must_halt_fu.html\}.
} 
military utility in the post-Cold War conflicts where protecting and winning the support of civilians was crucial. ${ }^{188}$

Drawing inspiration from the landmine letter published by US generals, ${ }^{189}$ at the outset of the final negotiations of the Convention on Cluster Munitions in May 2008, nine senior British military leaders published an open letter in The Times to the Secretary of State for Defense titled 'Cluster Bombs Don’t Work and Must be Banned'. They argued that CMs caused casualties both among civilians and the UK's own soldiers, were 'battlefield losers', and British support for a ban would 'strengthen our ability to use force effectively in the modern world' and prevent future proliferation of CMs to the 'wrong' actors. Thus, instead of relying on CMs, the UK government should 'equip [its] troops with the right weapons with which they will be able to fight and win future wars' ${ }^{190}$ In the words of an activist, the letter 'beautifully framed the issue' in a way to show that 'the military utility of cluster munitions would come from their prohibition'. ${ }^{191}$

The international NGO network, the Cluster Munition Coalition (CMC), similarly challenged the military effectiveness of CMs. As in the landmine campaign when NGOs sought to question 'whether mines are essential; not just useful', ${ }^{192}$ the CMC aimed at undermining arguments about the 'unique' military utility of CMs. It argued that despite military claims to the contrary, CMs had been used in recent conflicts as 'a weapon of convenience' without any specific advantages and other conventional weapons could easily perform the tasks allocated to CMs. ${ }^{193}$ NGOs seemingly spoke for the military by asserting that, 'soldiers... know these weapons are

\footnotetext{
188 E.g. UK House of Lords Hansard, 'Cluster Munitions’ (17 May 2007); UK House of Lords Hansard, ‘Conventional Weapons’ (15 November 2007), \{http://www.publications.parliament.uk/pa/ld200708/ldhansrd/text/71115\}.

189 Open letter to Clinton in the New York Times (3 April 1996).

190 'Cluster Bombs Don't Work and Must Be Banned', The Times (19 May 2008).

191 Interview 20090525.

192 Steve Goose, 'Plenary Session II, The Military Situation', in ICBL, Human and Socio-Economic Impact of Landmines, emphasis in original.

193 Cluster Munition Coalition, 'Prohibiting Cluster Munitions’.
} 
outdated' and needed 'good weapons' instead, ${ }^{194}$ while states unwilling to support a strong ban were repeatedly criticized for being 'more interested in protecting their obsolete cluster munitions than protecting civilians'. ${ }^{195}$

In April 2007, in its traditional role of seeking to engage with the military, the ICRC organized an expert meeting, focusing among other issues on the military and technical aspects of CMs. ${ }^{196}$ There, NGO representatives kept emphasizing that militaries had no data on submunition failure rates in combat, which made military claims of the weapons' proper and effective use baseless. ${ }^{197}$ In contrast to the 1996 ICRC report, this meeting did not reach a conclusion about the military utility of CMs. However, it did indicate the lack of reliable information and in-depth studies, thus casting doubt on military arguments and credibility on the issue.

In order to provide an authoritative military analysis, the Norwegian Ministry of Foreign Affairs tasked the Norwegian Defense Research Establishment with conducting research on military utility. The resulting report debunked assertions about the high efficiency of CMs, but was not a sweeping statement about their lack of utility. Instead, it significantly raised the bar those weapons had to meet by arguing that:

Cluster weapons do have a satisfactory or adequate effect against most targets. Under certain conditions the effect is quite good. However, no evidence has been found to claim that such weapons are far better than their alternatives to the extent that they are

\footnotetext{
${ }^{194}$ Mines Action Canada director quoted in Julie Burtinshaw, ‘Stop Cluster Bombs’, (22 March 2007), \{http://disarmament.suite101.com/article.cfm/stop_cluster_bombs\}.

195 CMC co-chair in Pax Christi Netherlands, 'Cluster Bomb Treaty Takes Shape', Press Release (25 May 2007), \{http://www.ikvpaxchristi.nl/files/Documenten/wap\%20cluster\%20munitie/Clustermunition/PRESS\%20RELEASE \%2025\%20May\%202007.doc\}; CMC, 'Global push to ban cluster bombs at crossroads - Governments called upon to keep protection of civilians at forefront of negotiations’, Press Release, (18 February 2008).

196 ICRC, Humanitarian, Military, Technical, and Legal Challenges.

197 John Borrie, 'The Road from Oslo: Emerging International Efforts on Cluster Munitions', Disarmament Diplomacy, 85(Summer 2007).
} 
indispensable [...] Cluster weapons do not constitute an irreplaceable capability on the battlefield. Alternatives exist, although in some cases they may be less effective than cluster weapons... Thus a prohibition of cluster weapons will not mean that a set of unique capabilities is lost. ${ }^{198}$

Yet, in practice very few weapons could pass the test of being 'indispensable’ and 'unique’. If that made them 'obsolete', and ultimately led to their prohibition, the military would indeed find itself with very few weapons left in its arsenal. ${ }^{199}$ Focusing on one particular type of weapon and raising the bar of military utility for it (from being useful under certain circumstances to being 'unique' in its capabilities) was an inherently political process. ${ }^{200}$ By demonstrating that CMs were neither 'indispensable' nor 'unique', the report made way for arguments that they were dispensable and outdated and strengthened the position of states advocating a ban by showing that it was backed by military analysis.

Thus, ban proponents not only amplified the humanitarian frame relying on their own humanitarian credentials. They also worked side-by-side with military partners to deflate the military utility counterframe from within by challenging military arguments and raising the standards of acceptability weapons need to meet.

\footnotetext{
${ }^{198}$ Ove Dullum, Cluster Munitions: Military Utility and Alternatives. FFI-report 2007/02345 (Norwegian Defense Research Establishment, 2008), pp. 3, 143, emphasis added.

${ }^{199}$ Richard Price, The Chemical Weapons Taboo (Cornell University Press, 1997), p. 5 has argued that 'the lack of decisive utility' has never precluded the entry of new weapons in military arsenals, and hence, the prohibition of chemical weapons could not be explained by their military ineffectiveness.

${ }^{200}$ As Price has argued, 'to the extent that a category of weapons technology carries the burden of extra political, legal, and moral baggage, the ordinary criteria of mere utility will just not do'; Price, 'Reversing the Gun Sights', p. 633.
} 
Stigmatizing weapons and ban opponents: implications for US practices and legitimacy ${ }^{201}$

The US was the first state to acknowledge the CM problem in the wake of NGO criticisms during the NATO Kosovo intervention. However, till mid-2007 it resisted efforts for an international instrument regulating these weapons. Then, it decided to support negotiations on CMs within the consensus-based Convention on Certain Conventional Weapons (CCW) and started pushing the issue forward. NGO members attributed this U-turn to the Oslo Process that was gathering speed without US participation. ${ }^{202}$ It was also likely motivated by the need to defend the US humanitarian credentials as the policy change came amidst statements highlighting the generous US contributions to demining and clearance of explosive remnants of war. ${ }^{203}$ As The Economist put it, 'Given the general mood of competition to be virtuous, America had little choice, perhaps, but to signal its own willingness to co-operate in limiting the humanitarian effects of mini-explosives'. ${ }^{204}$ At the CCW, the US kept emphasizing its lead in funding clean-up operations and announced the establishment of a quick reaction force to 'respond globally to short notice and emergent humanitarian operations that require the removal or mitigation of explosive hazards to protect civilian populations'. ${ }^{205}$

Throughout, the US kept asserting the military utility of the weapons and their contribution to saving the lives of American soldiers. Yet, after the Oslo Process adopted the Convention on Cluster Munitions (CCM) in May 2008, the Pentagon issued a new policy, which recognized 'the

\footnotetext{
${ }^{201}$ Here I focus on the CM case. For an examination of the effects of landmine stigmatization, see, Richard Price, 'Emerging Customary Norms and Anti-Personnel Landmines', in Christian Reus-Smit (ed.), The Politics of International Law (Cambridge University Press, 2004), pp. 106-30; Bower, 'Norms Without the Great Powers'. 202 Stephen D. Goose, 'Cluster Munitions: Ban Them’, Arms Control Today (Jan/Feb 2008), \{http://www.armscontrol.org/act/2008_01-02/goose.asp\}.

${ }^{203}$ US Department of State, 'United States Clearance of Unexploded Cluster Munitions', Fact Sheet, Office of the Spokesman (23 February 2007); ‘U.S. Intervention on Humanitarian Impacts of Cluster Munitions’, (20 June 2007); USA, 'Statement on the Outcome of the CCW Group of Government Experts Meeting', (22 June 2007).

204 'Cluster Munitions: A Change of Heart, or of Tactic?' (The Economist, 21 June 2007).

205 'U.S. Statement on Humanitarians Aspects of Cluster Munitions’, CCW-GGE (16 January 2008).
} 
need to minimize the unintended harm to civilians and civilian infrastructure associated with unexploded ordnance of cluster munitions’. It instituted that all CMs used by the US after the end of 2018 should result in 'no more than 1\% unexploded ordnance (UXO)', whereas with immediate effect, it directed that use of CMs exceeding the 1\% UXO rate had to be approved by the Combatant Commander. ${ }^{206}$ Although NGOs characterized the policy as 'too little, too late', ${ }^{207}$ it required a high reliability rate under all types of combat conditions. ${ }^{208}$ Because of the difficulty to meet this criterion, since 2005 the US has not produced any new CMs apart from sensor-fuzed weapons. ${ }^{209}$ In addition, according to the policy, by 2019 the vast majority of US CMs (95\%) would be scrapped - the same deadline for CM stockpile destruction the CCM sets. The policy remained silent on limiting the area effects of CMs, but it was a step toward addressing the reliability problem and by vesting use authority high in the command chain acknowledged that those were weapons of special concern and should be used with restraint.

However, at the end of 2017, not having managed to develop munitions with less than $1 \%$ UXO, the DoD suspended the 2008 policy to end the of use of submunitions that did not meet that criterion in 2019. While it reaffirmed the policy regarding new munition procurement, ${ }^{210}$ the new directive is a step back, sharply criticized by NGOs. ${ }^{211}$ Still, it remains to be seen if it will mark a change in US practice. If the landmine case is any guidance, it will probably not. Despite sliding back from the aspirational goal of developing landmine alternatives and joining the MBT under

\footnotetext{
206 Gates, ‘Memorandum'.

${ }^{207}$ Cluster Munition Coaltion, ‘US Out of Step with Allies with Hollow “New” Cluster Bomb Policy’, Press Release (8 July 2008).

208 That is, not just in testing or under averaged combat conditions.

${ }^{209}$ Landmine and Cluster Munition Monitor, 'United States: Cluster Munition Ban Policy’ (8 August 2016), \{http://www.the-monitor.org/en-gb/reports/2017/united-states/cluster-munition-ban-policy.aspx .

${ }^{210}$ Deputy Secretary of Defense, 'Memorandum, DoD Policy on Cluster Munitions’ (30 November 2017), \{https://www.defense.gov/Portals/1/Documents/pubs/DOD-POLICY-ON-CLUSTER-MUNITIONS-OSD07141517.pdf $\}$

${ }^{211}$ HRW, 'US Embraces Cluster Munitions’ (1 December 2017), \{https://www.hrw.org/news/2017/12/01/usembraces-cluster-munitions\}
} 
President Bush in 2004, the US has refrained from using landmines since 1991 (apart from a single mine in 2002), and President Obama ultimately strengthened the US commitment to a ban. ${ }^{212}$

Nevertheless, compared with anti-personnel landmines, the US has been far less willing to consider banning CMs. Although it has repeatedly stated that it is 'deeply concerned about the humanitarian impact' of $\mathrm{CMs}^{213}$ after the adoption of the Convention on Cluster Munitions, it declared, 'we do not support a sweeping ban on cluster munitions. Nor do we view the text negotiated in Dublin as establishing a new, general legal norm concerning the use of cluster munitions; they remain, in our view, a legitimate weapon when used appropriately'.214

Indeed, future 'appropriate' use of CMs by the US in ways that do not cause humanitarian problems could pose a challenge to their stigmatization. So far this hasn't happened despite an alleged US use of CMs in December 2009 in a strike against an al-Qaeda camp in Yemen. Amnesty International brought attention to it in June 2010 - the first and only reported US use of CMs since 2003. Despite Amnesty's report and a call from the CMC that the US confirm or deny the cluster use, ${ }^{215}$ no official response has ever been issued. This silence constitutes less than a frontal assault on the new norm. Moreover, the fact that in that strike, reportedly 41 civilians were killed and later

\footnotetext{
${ }^{212}$ Landmine and Cluster Munition Monitor, 'United States Mine Ban Policy’, (23 October 2017), \{http://www.themonitor.org/en-gb/reports/2017/united-states/mine-ban-policy.aspx $\}$. As in the landmine case, the main reason the military has offered for retaining the option to use unreliable CMs is the tense situation on the Korean peninsula. See, 'U.S. Will Keep Older Cluster Munitions, a Weapon Banned by 102 Nations' (New York Times, 1 December 2017), \{https:/www.nytimes.com/2017/12/01/us/cluster-munitions-pentagon-south-korea.html? rr=1\}.

${ }^{213}$ US Department of State, 'White Paper: Putting the Impact of Cluster Munitions In Context with the Effects of All Explosive Remnants of War' (15 February 2008).

214 'Opening Statement by Stephen Mathias, Head of U.S. Delegation to the CCW-GGE Meetings' (7 July 2008). Also, USA, 'Statement on proposed changes by the Group of 25 to the Group of Governmental Experts' (7 November 2008).

${ }^{215}$ Amnesty Internaitonal, 'Yemen: Images of missile and cluster munitions point to US role in fatal attack', Press Release (7 June 2010), \{https://web.archive.org/web/20100609220159/http://www.amnesty.org/en/for-media/pressreleases/yemen-images-missile-and-cluster-munitions-point-us-role-fatal-attack-2010-\}; Cluster Munition Coaltion, 'US: Confirm or Deny Use of Cluster Munitions in Yemen' (8 June 2010), \{http://www.stopclustermunitions.org/en-gb/media/news/2010/us-confirm-or-deny-use-of-cluster-munitions.aspx ..
} 
four more died and thirteen were wounded by unexploded submunitions, ${ }^{216}$ shows again that it is hard to use CMs 'appropriately'. Rather than undermining the new norm, this use could be seen as an aberrant case of a controversial practice - one of the first signs that a norm starts exerting influence is that the breaching behavior is concealed or denied, ${ }^{217}$ while those still engaging in it are portrayed as 'outcasts’.

Furthermore, the US has made some concrete steps that contribute to affirming a norm against CM use. Between 2013 and 2017, the US voted in favor of annual resolutions by the UN General Assembly and the Human Rights Council condemning the use of CMs by the Syrian government, in 2014 it supported a UN Security Council resolution expressing concern over CM use in South Sudan, and several times voiced concern about CM use in Ukraine. ${ }^{218}$

Domestic pressure for US compliance with the new norm has been coming from the US Senate, where senators, including the erstwhile advocate of a landmine ban, Patrick Leahy, have been active on the issue. In December 2008, Senators Feinstein and Leahy introduced a resolution calling on the US to sign the CCM and in 2013 sent a letter to President Obama urging for ratification. Earlier in 2007, they managed to pass with the 2008 Foreign Appropriations Bill a provision banning the sale and transfer of CMs with a tested failure rate of one or more percent and mandating that any country importing US CMs only use them against clearly defined military targets where no civilians are present. In March 2009, the US CM export ban was made permanent and in December, the Consolidated Appropriations Act 2010 was signed into law prohibiting the provision

\footnotetext{
${ }^{216}$ Landmine and Cluster Munition Monitor, 'United States’ (2016); Landmine and Cluster Munition Monitor, ‘United States: Cluster Munition Ban Policy’ (2015), \{http://the-monitor.org/en-gb/reports/2015/unitedstates/cluster-munition-ban-policy.aspx\}.

217 Thomas Risse and Kathryn Sikkink, 'The Socialization of Human Rights Norms into Domestic Practice: Introduction', in Thomas Risse, Stephen C. Ropp and Kathryn Sikkink (eds), The Power of Human Rights: International Norms and Domestic Change (Cambridge University Press, 1999), pp. 1-38.

${ }^{218}$ Landmine and Cluster Munition Monitor, 'United States: Cluster Munition Ban Policy’ (4 August 2017), \{http://www.the-monitor.org/en-gb/reports/2017/united-states/cluster-munition-ban-policy.aspx .
} 
of military assistance for CMs and the sale or transfer of CM technology with the stronger provision that their dud rate should be less than 1\% 'across the range of intended operational environments' ${ }^{219}$ In practice, these Congressional initiatives have halted any US exports of CMs apart from sensorfuzed weapons that on paper met the reliability standard. Yet, following outcry against Saudi Arabia's use of American sensor-fuzed weapons in Yemen, President Obama halted their exports in mid-2016, ${ }^{220}$ and with the growing stigma attached to CMs, the only manufacturer of sensor-fuzed weapons stopped producing them in August 2016, effectively ending all US production of CMs. ${ }^{221}$ Thus, the sensor-fuzed weapon - a high-tech and high-priced munition, ${ }^{222}$ used for the first time in 2003 was banned by the treaty in 2008 and went out of production in 2016 due to 'reduced orders, a volatile political environment, and international weapons treaties that negatively affect the “ownability” of its shares’.223

Apart from being constrained in its practices, the US has also suffered legitimacy deficit because of its active or more tacit resistance to the landmine and CM processes, respectively. In the landmine case, US opposition to the ban treaty process, its demands for exceptions in the treaty to accommodate US interests, and pressure on other states to support its positions turned the US

\footnotetext{
${ }^{219}$ HRW, Banning Cluster Munitions: Government Policy and Practice. Report (May 2009), p. 255; Cluster Munition Monitor, 'United States' (2017).

${ }^{220}$ John Hudson, 'White House Blocks Transfer of Cluster Bombs to Saudi Arabia', Foreign Policy (27 May 2016), \{https://foreignpolicy.com/2016/05/27/exclusive-white-house-blocks-transfer-of-cluster-bombs-to-saudi-arabia/\}.

${ }^{221}$ John Hudson, 'Last Remaining U.S. Maker of Cluster Bombs Stops Production', Foreign Policy (31 August 2016), https://foreignpolicy.com/2016/08/31/last-remaining-u-s-maker-of-cluster-bombs-stops-production/\}. 222 One CBU-97 costs around USD 370,000. Based on data from HRW, 'Air Force Procurement Requests', Backgrounder (2005), \{https://web.archive.org/web/20090118011714/https://www.hrw.org/legacy/backgrounder/arms/clustermunitions/5. $\underline{\mathrm{htm}}$ \}. For comparison, most precision-guided bomb cost less per unit. JDAM kits cost about USD 25,000, while laser-guidance kits vary depending on bomb size from USD 40,000 to 70,000; Tamir Eshel, 'The High Cost of Precision Attack' (6 May 2011), \{http://defense-update.com/20110506_precision_attack.html\}. A 4000lb. bunker buster, GBU-28, costs USD 145,600, less than half the price of the sensor-fuzed weapon (http://www.globalsecurity.org/military/systems/munitions/gbu-28-specs.htm).

${ }^{223}$ Manufacturer representative quoted in Bryan Schatz, 'This American Company Is Finally Getting Out of the Cluster Bomb Business' (1 September 2016), \{http://www.motherjones.com/politics/2016/08/textron-cluster-bomb-manufacturerending-production
} 
into a target of NGO criticism. ${ }^{224}$ In the words of the ICBL coordinator, Jody Williams, 'when its arm-twisting failed', the US 'decided to stand outside the tide of history'. ${ }^{225}$ To regain its humanitarian standing, the US then increased its demining funding and ever since has kept emphasizing that it is the 'world leader in humanitarian mine action'. ${ }^{226}$ Yet, US opposition to the Mine Ban Treaty (MBT) undermined its diplomatic leverage in the later negotiations of the International Criminal Court, where it was seen as an 'outcast' and 'a deadbeat'. ${ }^{227}$ The media portrayed it as 'siding with rogue states' and 'developing a worrisome habit of getting on the wrong side of history'. ${ }^{228}$ The US found itself again isolated and bearing the brunt of criticism for not supporting a strong and independent court, ${ }^{229}$ clearly losing credibility and legitimacy as an international leader.

The US did not participate in the CCM negotiations. However, given that predominantly American (and British) use of CMs in Kosovo in 1999 and Afghanistan and Iraq in 2001-2003 brought the issue to the fore (before Israeli CM use in 2006 gave momentum to the Oslo Process), the NGO campaign was very much centered around de-legitimating American military practices. The US also became the focus of criticism, when during the final negotiation conference, the State Department held a briefing on CM policy. While it emphasized that the US was 'deeply concerned

\footnotetext{
${ }^{224}$ Leon V. Sigal, Negotiating Minefields: The Landmines Ban in American Politics (Routledge, 2006), pp. 201-205.

${ }^{225}$ Quoted in David Usborne, 'She Battles Landmines, Bullies, and Bill', The Independent (12 October 1997).

${ }^{226}$ US Department of State, 'U.S. Landmine Policy’ (27 February 2004),

\{http://www.state.gov/t/pm/wra/c11735.htm \}; Ambassador Karl F. Inderfurth, 'Demining 2010 initiative coordination of resources for mine action', The RUSI Journal, 143:1 (1998), pp. 9-10; Wareham, 'Rhetoric and Policy Realities in the United States', p. 239; US Department of State, 'United States Leadership in Clearing Landmines and Saving Lives' (13 November 2007), \{https://2001-2009.state.gov/r/pa/prs/ps/2007/nov/95071.htm \}; US Department of State, 'U.S. Global Leadership in Landmine Clearance and Conventional Weapons Destruction' (3 April 2015), \{https://www.state.gov/r/pa/prs/ps/2015/04/240274.htm\}.

${ }^{227}$ Ramesh Jaura, 'Compromise Yes, Clout No', Terra Viva: The Conference Daily Newspaper, 1 (15 June 1998), p. 3; 'Political Will is Real Test for Court', Terra Viva, 5 (19 June 1998), p. 5; Farhan Faq, 'Increasingly, US an Isolated Voice', Terra Viva, 6 (22 June 1998), p. 4.

${ }^{228}$ Quoted in ICC Monitor, 10 (November 1998), \{http://www.iccnow.org/documents/monitor10.199811.pdf\}.

${ }^{229}$ David Scheffer, All the Missing Souls: A Personal History of the War Crimes Tribunals (Princeton University Press, 2012), pp. 220, 217.
} 
about the humanitarian impact' of CMs and highlighted the American lead in battlefield cleaning, it also asserted that if no changes in the convention were made, the US would be unable to participate in peacekeeping or disaster relief operations. ${ }^{230}$ This stance led to accusations that the US was 'cynically' trying to 'intimidate the countries that are negotiating in good faith'. ${ }^{231}$ The CM ban became one more treaty in a string of examples of US obstructionism to international norms and law that both showed the lack of US legitimacy and further deprived it of such. From a benevolent power with special responsibilities for ensuring international peace and security, the US emerged as a retrograde force and a threat to international norms.

Thus, US policies and practices on CMs show that it has felt the stigma of CMs and taken steps to address their humanitarian effects. Although the US still insists on the legality of CMs, the evolution in its positions has contributed to reinforcing the norm that weapons should be used in a way that does not cause excessive civilian harm. Reinforcing these general IHL principles and applying them conscientiously to the use of CMs in turn makes such use highly improbable and indirectly strengthens the case for a ban.

\section{Conclusion: transforming war and law from within}

According to a prominent critic of IHL, the dominance of its principles of military necessity and proportionality between military and humanitarian costs makes it 'difficult to image how else one

\footnotetext{
${ }^{230}$ US Department of State, 'Ambassador Mull Briefs on U.S. Cluster Munitions Policy’, Briefing (21 May 2008), \{http://web.archive.org/web/20080601032416/http://www.america.gov/st/texttransenglish/2008/May/20080522163101eaifas0.8921015.html \}.

${ }^{231}$ Cluster Munition Coalition, 'Campaigners Call On U.S. To Stop Bullying Negotiators' (23 May 2008), \{http://www.stopclustermunitions.org/en-gb/media/news/2008/campaigners-call-on-us-to-stop-bullying-neg.aspx $\}$; Jody Williams, 'US Subverts the Cluster Bomb Ban', Boston Globe (24 May 2008); 'US “Bullying” Hurts Cluster Bomb Ban Work’, Reuters (23 May 2008).
} 
would talk about the use of force'. ${ }^{232}$ This is a valid critique of the hegemonic legal discourse that has become part and parcel of warfare, ${ }^{233}$ and NGO campaigners face a constant choice between buying into the cost-benefit analysis of military and legal thinking and defending civilian immunity without exceptions. However, it does not have to be an either or choice. The landmine and CM cases offer an example of resolving this tension by reshaping understandings of what is at stake in the balancing act. NGOs did so by tilting the scales toward humanitarian considerations, using the legal principles and the military's own arguments to critique actual military practices, and finally prioritizing civilian protection - an ideal only immanent in IHL. Law can thus first inform and then make room for further humanitarian considerations - an example of immanent critique practiced by NGOs in the landmine and CM cases.

The MBT and CCM strengthen the prohibition of indiscriminate attacks and the CCM includes guidelines to 'avoid indiscriminate area effects and the risks posed by unexploded submunitions' that could be extended to other practices severely affecting civilians. ${ }^{234}$ Building upon the two treaties and the IHL principles they embody will not lead to swift or radical changes in state practice. Still, it can serve as a first step on the way to stigmatizing methods and means of warfare that cause heavy civilian suffering.

But couldn't NGOs be more imaginative and effective in transforming arms control and disarmament practices? It is true that ultimately their success depended on depoliticizing the issues and distancing themselves from radical movements such as those animated by pacifism and a desire for total disarmament. ${ }^{235}$ This is a distinction that NGOs involved in banning CMs and

\footnotetext{
${ }^{232}$ Kennedy, The Dark Sides of Virtue, p. 294, emphasis in original.

${ }^{233}$ Kennedy, 'Lawfare and Warfare'; Kennedy, Of War and Law.

${ }^{234}$ Rappert and Moyes, 'The Prohibition of Cluster Munitions'.

${ }^{235}$ Neumann, 'Harnessing Social Power’; Ole Jacob Sending and Iver B. Neumann, 'Governance to Governmentality: Analyzing NGOs, States, and Power’, International Studies Quarterly, 50 (2006), pp. 651-672; Nikola Hynek, 'Conditions of Emergence and Their (Bio)political Effects: Political Rationalities, Governmental Programmes and
} 
landmines often invoke. It is also true that NGOs had to make compromises and calibrate their demands in order to secure state agreement to the treaties and thereby establish the weapon stigmas. ${ }^{236}$ A comparison of the two campaigns also shows that over time NGOs have become more professionalized, and one might say, tamed. Although the landmine campaign was never a huge grassroots movement, it still used more public advocacy and confrontational politics compared to the CM campaign. NGO members argue that this is natural as gaining access to decision-making for the most part obviates the need for outsider tactics of influence. ${ }^{237}$ As has been pointed out, the close relationship between leading governments and NGOs does not necessarily mean the cooptation of the latter. ${ }^{238}$ Instead, it has been key in moving the NGO agenda forward. ${ }^{239}$ It does mean that some compromises need to be made and that change would sometimes be late to come, would come in fits and starts, and will not lead to an overhaul of the system. In practice, the success of the landmine and CM campaigns rested on not questioning the legitimacy of the use of force in general and of the military in particular. But paradoxically, the inherent limitations of professionalized NGOs also give them a chance to make a difference in desecuritizing military practices and securing vulnerable human beings. ${ }^{240}$

The landmine and CM campaigns have also been criticized for stigmatizing the weapons themselves as the agents causing suffering rather than directing their critiques at the real users and

Technologies of Power in the Landmine Case', Journal of International Relations and Development, 11 (2008), pp. 93-120; Carpenter, 'Lost Causes'.

${ }^{236}$ For example, when the MBT was negotiated, demands from some NGO members to include in the treaty also anti-tank mines or CMs were sidelined. In the CCM, an exception was made for the most advanced sensor-fuzed weapons that arguably did not have the humanitarian effects of CMs. Despite opposing the inclusion of an interoperability clause in the CCM, NGOs also chose to acquiesce to it, but strongly criticize it to limit its practical impact.

${ }^{237}$ Interview 20121123.1.

${ }^{238}$ Neumann, 'Harnessing Social Power'.

${ }^{239}$ Thomas Nash, 'Civil Society and Cluster Munitions: Building Blocks of a Global Campaign', in Mary Kaldor et al. (eds), Global Civil Society 2012 (Palgrave, 2012), pp. 134-5.

${ }^{240}$ For example, the victim assistance clause of the CCM was considerably stronger compared to the MBT. See, Bonnie Docherty, 'Breaking New Ground: The Convention on Cluster Munitions and the Evolution of International Humanitarian Law', Human Rights Quarterly, 31 (2009), pp. 934-963. 
the militarized world order, thus indirectly legitimizing high-tech military violence and 'fix[ing] quite restrictive limits on the range of weapons that might be singled out for prohibition’, ${ }^{241}$ namely, a few 'pariah weapons'. ${ }^{242}$ A look at a current campaign against lethal autonomous weapons, however, reveals other ways in which the previous campaigns are much more directly implicated without necessarily legitimizing high-tech weaponry. NGOs made CMs and landmines the ultimate evildoers, but an underlying argument was that they were killing on their own even decades after soldiers used them. There was no human control over the ways in which landmines killed unsuspecting civilians. These were the mines banned by the MBT. Mines used in control mode with human decisions about exploding them remained legal. The same argument about the need for human control over the destructive power of weapons and ultimately human responsibility for life and death decisions animates a campaign against autonomous killing weapons led by many of the same NGOs working on landmines and CMs. ${ }^{243}$ Although an attempt to fuse agency with the weapons is present in the campaign name, 'Campaign to Stop Killer Robots', this is exactly the point - weapons killing on their own should not be allowed. Rather than low-tech weapons, the campaign targets some of the most advanced systems under development in the richest military powers. It is also preventive in character rather than reactive as the landmine, and to a large extent, the CM campaigns were. Although the killer robot campaign leaves the IHL framework unquestioned, arguably it does not legitimize high-tech killing. It remains to be seen how much this campaign would achieve, but so far it has gained some traction despite its much more limited

\footnotetext{
${ }^{241}$ Beier, 'Dangerous Terrain', p. 172; Larrinaga and Sjolander, '(Re)presenting Landmines’.

${ }^{242}$ Turner, Cooper, and Pugh, 'Institutionalized and Co-Opted', p. 87.

${ }^{243}$ Eight of the ten NGOs on the Steering Committee of the campaign were previously and currently associated with the landmine and CM campaigns, with its coordinator, Mary Wareham, a former coordinator of the US landmine campaign and long-time HRW researcher on landmines and CMs \{https://www.stopkillerrobots.org/about-us/\}.
} 
support among NGOs compared to the above cases. ${ }^{244}$ A year after its creation in 2012, the NGO campaign managed to insert the issue in the CCW agenda where informal talks on fully autonomous weapons started in 2014. In December 2016, a formal Group of Governmental Experts was established to discuss the issue in 2017 - a step that has previously led to CCW negotiation mandates on landmines and CMs, although no progress in this direction has so far been made regarding autonomous killing weapons. ${ }^{245}$ By the end of 2017, 22 states had signaled support for a ban ${ }^{246}$ and activists have been optimistic that a treaty would be concluded, though it is unclear when or what it would cover. ${ }^{247}$ It is clear, however, that without the path blazed by the previous ban treaties and without the experience campaigners had gained in humanitarian arms control negotiations and the networks they had established, the Campaign to Stop Killer Robots would not have been able to make the headway that it has. ${ }^{248}$

Finally, using the precedent of banning landmines and CMs, NGOs ultimately turned their sights toward a total ban on nuclear weapons. In an example of ongoing immanent critique, NGOs have come full circle. At its start, the ICBL distanced itself from a full disarmament agenda and indeed argued that landmines were the real 'weapons of mass destruction in slow motion'. Twenty years later, the question became, how is it possible that landmines and CMs are banned, but not

\footnotetext{
${ }^{244}$ As of April 2017, 4 years after its official launch, the campaign had 63 members. The CMC launched with the support of 85 NGOs and 4 years later had 238 members (https://web.archive.org/web/20080101032735/http://www.stopclustermunitions.org/dokumenti/dokument.asp?id=3 3). Four years after its beginning, the ICBL had 650 members; ICBL, Towards a Global Ban on Anti-Personnel Mines, International Strategy Conference (Ottawa, 3-5 October 1996), p. 18.

${ }^{245}$ The CCW mandate for 2018 remained at the discussion stage.

${ }^{246}$ Campaign to Stop Killer Robots, 'Support Grows for New International Law on Killer Robots' (17 November 2017), \{https://www.stopkillerrobots.org/2017/11/gge/\}.

${ }^{247}$ Madison Margolin, 'How Does the Story of Killer Robots End?’ (23 February 2017), \{https://www.inverse.com/article/28153-army-killer-robots\}.

${ }^{248}$ It has been argued that despite the advocacy against autonomous weapons by a loose network of scientists, the campaign only took off when HRW joined, after Jody Williams and Article 36, the latter made up of core CMC campaigners, played bridge-building roles; Carpenter, 'Lost Causes'.
} 
the most indiscriminate weapons? ${ }^{249}$ Rather than legitimating the weapons of great powers (such as advanced autonomous systems and nuclear weapons), the prior landmine and CM bans have created the conditions for challenging them. A group of NGOs energized by the example of the MBT and CCM and some of the same individuals and organizations involved in the respective campaigns have finally brought about a change in nuclear disarmament by reframing the issue around the severe humanitarian effects of any incidental or intentional explosion of nuclear weapons. ${ }^{250}$ After a UN First Committee resolution to launch negotiations for a ban on nuclear weapons, in July 2017 a treaty banning the production, stockpiling, transfer, and use of nuclear weapons (including the threat of use) was adopted with 122 votes in favor and against the wishes of the nuclear powers and all NATO members. ${ }^{251}$ There are considerable doubts and uncertainty about the new treaty's ethical implications and effects on the nuclear powers, ${ }^{252}$ on the nonproliferation regime, ${ }^{253}$ and nuclear politics and existing power structures. ${ }^{254}$ However, it is already an achievement in itself that the majority of states committed to negotiating such a treaty

\footnotetext{
${ }^{249}$ E.g. International Campaign to Abolish Nuclear Weapons (ICAN), 'Outlawing Inhumane Weapons', \{http://www.icanw.org/the-facts/catastrophic-harm/outlawing-inhumane-weapons/\}. Also, ICAN, 'UN votes to outlaw nuclear weapons in 2017’ (27 October 2016), \{http://www.icanw.org/campaign-news/un-votes-to-outlawnuclear-weapons-in-2017\}.

${ }^{250}$ ICAN, Catastrophic Humanitarian Harm (Report, August 2012), \{http://www.icanw.org/wpcontent/uploads/2012/08/catastrophicharm2012.pdf\}; Article 36, Banning Nuclear Weapons (Report, February 2013), \{http://www.article36.org/wp-content/uploads/2013/02/Report_web_23.02.13.pdf \}

251 'Joint Press Statement from the Permanent Representatives to the United Nations of the United States, United Kingdom, and France Following the Adoption of a Treaty Banning Nuclear Weapons', 7 July 2017, \{https://usun.state.gov/remarks/7892 . The Netherlands, the only NATO country that participated in the negotiations, was the only one to vote against the treaty; 'About the treaty to prohibit nuclear weapons' (7 July 2017), \{http://www.icanw.org/campaign-news/about-the-treaty-to-prohibit-nuclear-weapons/\}.

${ }^{252}$ See, for example, Heather Williams, 'Why a Nuclear Weapons Ban is Unethical (For Now)', The RUSI Journal, 161:2 (2016), pp. 38-47.

${ }^{253}$ Harald Müller, 'The Nuclear Non-proliferation Treaty in Jeopardy? Internal Divisions and the Impact of World Politics', The International Spectator, 52:1 (2017), pp. 12-27.

${ }^{254}$ Given the long history of antinuclear activists highlighting the unthinkable effects of nuclear weapons, in line with radical critiques, it has been argued that by reproducing this dominant discourse and working through established international institutions, the humanitarian initiative 'carries with it limitations that render the approach not only ultimately ineffectual, but also potentially damaging'. See, Laura Considine, 'The "Standardization of Catastrophe”: Nuclear Disarmament, the Humanitarian Initiative and the Politics of the Unthinkable', European Journal of International Relations, 23:3 (2017), pp. 681-702, at p. 689.
} 
in the hopes that it would disrupt the nuclear status-quo and add a legal dimension to the normative stigma against the use of nuclear weapons. And in a symbolic of recognition of the importance of this achievement, the International Campaign to Abolish Nuclear Weapons was awarded the 2017 Nobel Peace Prize. ${ }^{255}$

Relying entirely on IHL (re)interpretations to move issues forward is not ideal and can become a hindrance at a certain point. Both NGOs and scholars have recognized that fact. ${ }^{256}$ Yet, using the dominant legal frame for humanitarian objectives and ultimately turning it upon dominant powers, has also empowered NGOs and the people facing the threats of armed conflict and dire post-conflict situations. As argued, the use of IHL as a departure point for critiques of CMs and landmines has been a form of immanent critique. By critiquing the dominant legal and military order using its own fundamental principles and showing how military practice fails to observe them, NGOs pry open niches for transformation. Such transformations may be modest and leave the core structure intact. Still, they limit the practices and legitimacy of dominant US power and over time cumulate toward a reconsideration not only of the legitimate means, but also of the legitimate use of force.

Exploring the ways in which NGO actors engage in transformative politics grounded in political realities, thus has both theoretical purchase and real life relevance. While it is important to acknowledge and critique the compromises and silences accompanying such attempts at transformation of the 'prevailing security regimes', ${ }^{257}$ they cannot be rejected out of hand as either legitimizing or strengthening a militarized hegemonic order. By paying close attention to both the

\footnotetext{
255 'Nobel Peace Prize awarded to anti-nuclear weapons campaigners’ (CNN, 6 October 2017), \{http://edition.cnn.com/2017/10/06/world/nobel-peace-prize/index.html\}

${ }^{256}$ Interview 20121123.2; Ritu Mathur, 'Practices of Legalization in Arms Control and Disarmament: The ICRC, CCW and Landmines’, Contemporary Security Policy, 33:3 (2012), pp. 413-436.

${ }^{257}$ Wyn Jones, 'Message in a Bottle', p. 312.
} 
discursive processes of banning weapons and their actual effects on the major military power, the article shows that immanent critique can still be a vehicle to freeing vulnerable people from some of the most incapacitating threats in their lives and gradually limiting the violence of war. 